\title{
DISASTERS AND YOUTH: A META-ANALYTIC EXAMINATION OF POSTTRAUMATIC STRESS
}

\author{
A Dissertation \\ Submitted to \\ The Temple University Graduate Board
}

in Partial Fulfillment

of the Requirements for the Degree

DOCTOR OF PHILOSOPHY

\section{By}

Jami M. Furr

May, 2010 
(C)

by Jami M. Furr

2010

All Rights Reserved 


\author{
ABSTRACT \\ DISASTERS AND YOUTH: \\ A META-ANALYTIC EXAMINATION OF POSTTRAUMATIC STRESS \\ by Jami M. Furr \\ Doctor of Philosophy \\ Temple University, May, 2010 \\ Major Advisor: Dr. Philip Kendall
}

Objective: A sizable body of literature has now examined posttraumatic stress (PTS) symptoms in youth in the aftermath of disaster. Meta-analysis is the preferred tool with which to inform funding decisions, service delivery, and public policy. Method: The present meta-analysis quantitatively synthesized this literature ( $k=96$ studies; Total $N=$ $74,154)$, summarizing the magnitude of overall associations between disasters and youth PTS, and identifying child, disaster, and study method factors associated with variations in the magnitude of these associations. Results: Despite variability across studies, disasters had a significant effect on youth PTS symptoms, falling in the small-to-medium range of magnitude. Aspects related to pre-existing child characteristics, the disaster and the child's disaster exposure, and study methodology are significantly associated with variations in the magnitude of disaster effects on youth PTS symptoms. Specifically, female gender, higher death toll, closer proximity, personal loss, and perceived threat and distress at the time of the event were each associated with increased post-disaster PTS in youth. Regarding methodological factors, studies conducted within the first year postdisaster, studies that used established PTS measures, and studies that relied on childreport data identified a significant effect on youth PTS, whereas studies conducted after 
the first year, studies relying on non-established measures, and studies relying on parentreport data did not. Conclusion: In the aftermath of disasters, governmental funding agencies and private foundations provide substantial resources for child services following disasters. The present meta-analytic findings can help to inform optimal allocation of these resources and targeted intervention efforts, as well as the development and refinement of new interventions for youth suffering in the aftermath of disasters. 


\section{ACKNOWLEDGMENTS}

I would like to acknowledge the efforts of those individuals who assisted on this project and without whom this dissertation would not have been completed: Dr. Jonathan Comer, Julie Edmunds, M.A., and Dr. Philip C. Kendall. I would also like to thank my dissertation advising committee for their thoughtful recommendations and suggested changes, including Dr. Deborah Drabick, Dr. Richard Heimberg, Dr. Ronald Brown, Dr. Peter Marshall, and Dr. Marsha Weinraub. I would like to extend my loving gratitude to my Mom and Dad, Shayna, Justin, and Marlene and Ron Comer, for their continued support and for always believing in me. Thank you to my dear friends for all of their encouragement and kindness. And finally, I would like to thank my husband, Jon, who has helped me get through the good and the bad, and to continue laughing all the way through. 


\section{TABLE OF CONTENTS}

$\begin{array}{lll}2 & \text { Page }\end{array}$

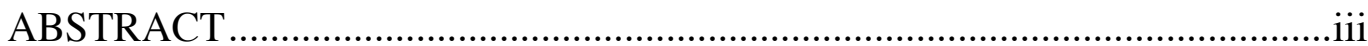

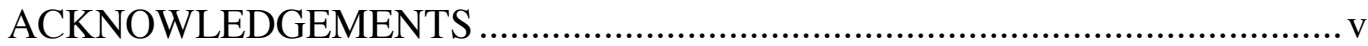

LIST OF TABLES ........................................................................................

LIST OF FIGURES ............................................................................ viii

CHAPTER

1. BACKGROUND AND SIGNIFICANCE ….......................................... 1

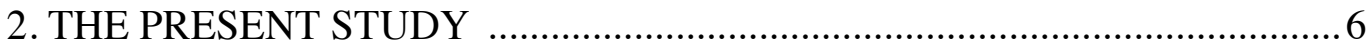

Research Design and Methods .......................................................

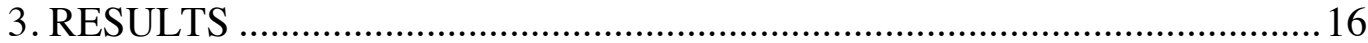

Characterizing the Literature ..................................................... 16

Analysis of All Effect Sizes .............................................................20

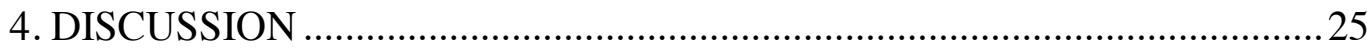

Limitations and Future Directions .................................................... 28

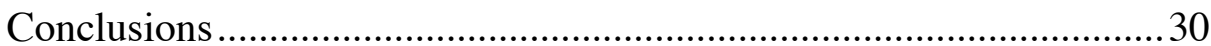

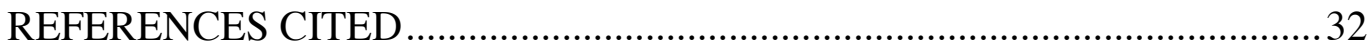




\section{LIST OF TABLES}

Table

Page

1. Characteristics of Empirical Studies Examining Posttraumatic Stress in Youth Following a Disaster .53

2. Methodological Characteristics of Empirical Studies Examining Posttraumatic Stress in Youth Following a Disaster.

3. Characteristics of Disasters and Disaster Experiences in Empirical Studies Examining Posttraumatic Stress in Youth Following a Disaster

4. Stem-and-Leaf Plot of All Effect Sizes $(r s)$

5. Stem-and-Leaf Plot of Gender Effect Sizes ( $r \mathrm{~s})$ 78

6. Effects of Proximity, Peritraumatic Distress, and Disaster-related Loss on Youth Post-Disaster PTS: Results of Random-Effects Meta-Analyses ....

7. Effects of Disasters on Youth PTS by Measurement Psychometric Quality, Informant, Study Period, and Measurement Mode: Results of Random-Effects Meta-Analyses 


\section{LIST OF FIGURES}

Figure

Page

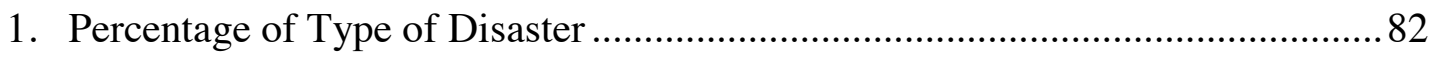

2. Weighted Prevalence of Post-disaster Loss and Injury.................................... 83

3. Weighted Prevalence of Peritraumatic Distress in the Overall, Affected, and Combined Samples............................................................................. 84

4. Weighted Prevalence of Probable and Diagnosed PTSD in the Affected

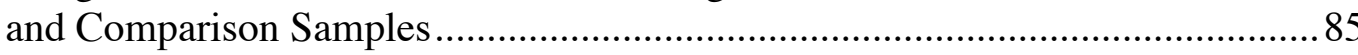

5. Weighted Prevalence of Reexperiencing, Avoidance, and Arousal Symptoms in the Affected and Comparison Samples.........................................86

6. Weighted Prevalence of Probable and Diagnosed PTSD by Gender ................. 87

7. Linear Trend in Pooled $r$ Effect Size of PTS Symptoms in Relation to Death Toll 


\section{CHAPTER 1}

\section{BACKGROUND AND SIGNIFICANCE}

Disasters are destructive occurrences that disrupt and overwhelm entire communities, confront every society, and collectively affect as many as thirty-three million individuals worldwide in a given year (International Federation of Red Cross and Red Crescent Societies, IFRC, 1998). There is evidence that the incidence of disasters is increasing (IFRC, 2004), and when disasters strike, a great many youth are in close proximity and are vulnerable to directly witnessing massive destruction, seeing dead or injured people, being involved in a school evacuation, losing a loved one, viewing physical damage or ruins, and/or being forced to relocate residency. Such diverse phenomena as hurricanes, earthquakes, floods, tsunamis, brushfires, terrorist attacks, mass transportation disasters, and nuclear waste accidents are associated with elevated rates of psychopathology and impairment in children and adolescents (e.g., Hoven et al., 2005; La Greca, Silverman, Vernberg, \& Prinstein, 1996; March, Amaya-Jackson, Terry \& Costanzo, 1997; Pynoos et al., 1993; see Furr, 2007 for a review). The most consistent finding is that youth living in regions that have experienced a disaster subsequently exhibit elevated rates of re-experiencing, avoidance/emotional numbing, and hyperarousal (i.e., posttraumatic stress, PTS, symptoms). PTS and posttraumatic stress disorder (PTSD) are associated with considerable impairment and difficulty, and when left untreated are associated with subsequent depression, anxiety, substance abuse, and conduct disorder, and overall impaired quality of life (e.g., Giaconia et al. 1995; Vernberg \& Varela, 2001). Accordingly, examining the impact of disasters on youth PTSD and PTS symptoms constitutes a matter of great public health concern. 
The extent to which individual children evidence PTS symptoms in the wake of disasters varies greatly (see Furr, 2007, unpublished manuscript). Acknowledging the multi-level ecology of child development (see Bronfenbrenner, 1979; Cicchetti \& Cohen, 1995; Mohr, 2002), guiding frameworks offered by Green et al. (1991), La Greca and colleagues (1996; La Greca \& Silverman, 2006; Silverman \& La Greca, 2002; Vernberg, La Greca, Silverman, and Prinstein, 1996), and Weems and Overstreet (2008) broadly conceptualize domains of influence that affect children's post-disaster functioning. Among these domains of influence, pre-existing aspects of the child (e.g., gender, age), and aspects of the disaster and disaster exposure (e.g., child proximity to disaster, perceived threat to self) have been well studied. In addition, aspects related to study methodology (e.g., sampling, measurement, timing of assessment) may affect documented post-disaster PTS levels in youth (Pfefferbaum \& North, 2008).

Across the child post-disaster literature, age and gender have been the most consistently studied pre-existing characteristics of the child. A number of studies that have included examination of gender effects find girls to evidence more PTS than boys (e.g., Barnes et al., 2005; Burke et al., 1986; Foa et al., 2001; Garrison et al., 1995; Gobble, Swenny, \& Fishbein, 2004; Lengua et al., 2005; Whalen et al., 2004). Analyses of age has produced more mixed findings, with some studies finding no age differences (e.g., Jeney-Gammon et al., 1993; Schuster et al., 2001), and other studies finding older children to show greater PTS than younger children (e.g., Garrison et al., 1995; Saylor et al., 2003; Terr et al., 1997). Importantly, although analyses of age effects across studies have produced mixed findings, given that gender differences in internalizing symptoms typically emerge at puberty (e.g., Angold, Worthman, \& Costello, 2003), there may exist 
a gender by age interaction, such that the effect of gender on PTS symptoms is stronger for older youth.

Aspects of the disaster and disaster exposure have been examined, including objective and subjective elements of the child's disaster experience and environment that may be associated with post-disaster functioning. Regarding objective elements, many studies have examined "dose effects," and found that the child's physical proximity to the disaster is negatively associated with subsequent PTS symptoms (i.e., youth in closer proximity display greater PTS; e.g., Schuster et al., 2001; Stuber et al., 2002). In contrast, a handful of other studies have found limited support for a proximity effect (e.g., Evans \& Oehler-Stinnett, 2006). Regarding subjective elements, a number of studies find peritraumatic distress (e.g., perceived life-threat and general distress at time of disaster), predicts post-disaster PTS (Garrison et al., 1995; Green et al., 1991; 1994; La Greca et al., 1996; 1998; Nader, Pynoos, Fairbanks, \& Frederick, 1990; Pfefferbaum, North, et al., 2003; Pynoos, Frederick, et al., 1987; Pynoos, Nader et al., 1987; Thienkura et al., 2006; Vernberg et al., 1996). Personal loss (e.g., loss of a loved one) has also been associated with post-disaster PTS (e.g., Brown \& Goodman, 2005; Goenjian et al., 1995; Green et al., 1994; Lengua et al., 2005; Pfefferbaum, North, et al., 2006; Pfefferbaum, Nixon, Krug, et al., 1999; Pfefferbaum, Nixon, Tucker, et al., 1999; Schwarz \& Kowalski, 1991; Stuber et al., 2002; Thienkura et al., 2006). Importantly, between-disaster differences have not been examined within empirical studies (e.g., PTS differences following natural vs. man-made disasters, relationships between disaster death toll and PTS).

Less acknowledged in determining documented post-disaster PTS rates in youth have been aspects related to study methodology. A small number of studies used 
structured diagnostic interviews (e.g., Asarnow et al., 1999; Bolton et al., 2000; Yule et al., 2000), whereas a majority of studies relied on diagnostic screeners or self-report questionnaires (e.g., Barnes et al., 2005; Goenjian et al., 1995; 2001; Green et al., 1991; Hoven et al., 2005; March et al., 1997; Pynoos, Frederick, et al., 1987; Scrimin et al., 2006; Thienkura et al., 2006), which identify "probable" rates of PTSD (i.e., individuals at high probability for meeting diagnostic criteria). Screeners and self-report questionnaires likely identify higher rates of pathology than diagnostic interviews (North \& Pfefferbaum, 2002; Pfefferbaum \& North, 2008). Cross-sectional comparisons of prevs. post-disaster PTS may provide different estimates than within-subjects comparisons. Due to recall bias, retrospective pre-disaster data (provided within-subjects at postdisaster) may also provide differential estimates of the effect of disasters on PTS symptoms in youth, as might post-disaster comparisons between exposed and nonexposed youth. Moreover, research has found parent-child concordance rates to range from low to moderate (Achenbach, McConaughy, \& Howell, 1987; De Los Reyes \& Kazdin, 2004), with concordance for childhood internalizing problems being particularly low (e.g., Comer \& Kendall, 2004; Grills \& Ollendick, 2003). Thus, it is likely that documented post-disaster PTS symptoms in youth are affected by who is reporting on them (e.g., parent, child, teacher). Finally, the post-disaster assessment period likely affects PTS findings. In the absence of evidence, it is misguided to infer that PTS symptoms identified during the recovery and reconstruction phases (i.e., months or years after the event; Silverman \& La Greca, 2002; Valent, 2000) would be present at recoil (i.e., immediately after the event occurs), post-impact (i.e., days to weeks after the event), or upon long-term follow-up (e.g., greater than two years later). 
Given research documenting the adverse impacts of disasters upon youth, associations devoted to the needs of youth have developed task forces and resolutions (e.g., American Academy of Pediatrics, Work Group on Disasters, 1995; Levant, 2002; Vogel \& Vernberg, 1993; Vernberg \& Vogel, 1993) that place the empirical understanding of children's needs in the aftermath of disasters at the forefront of their agendas. Governmental funding agencies and private foundations provide substantial resources for child services following disasters. To optimally inform the allocation of resources and targeted intervention efforts, there is a need to synthesize that which we have learned about the effects of disasters on children and adolescents.

Meta-analytic procedures provide a quantitative, accepted, and respected approach to the synthesis of a body of empirical literature. Literature reviews have moved away from the qualitative summary of studies to the quantitative analysis of the reported findings of the studies (e.g., Cooper \& Rosenthal, 1980; Rosenthal \& Rosnow, 1991). By summarizing the magnitude of overall relationships found across studies, determining factors associated with variations in the magnitude of such relationships, and establishing relationships by aggregate analysis, meta-analytic procedures provide more systematic, exhaustive, objective, and representative conclusions than qualitative reviews (Rosenthal, 1984). To understand the effect of disasters on PTS symptoms in youth, as well as the factors associated with variations in this effect, meta-analysis is the preferred tool with which to inform funding decisions, service delivery, and public policy. 


\section{CHAPTER 2}

\section{THE PRESENT STUDY}

The present study used meta-analytic procedures to examine the magnitude of the effect of disasters on youth PTS symptoms, as well as factors associated with variations in the effect of disasters on youth PTS symptoms. Specifically, the present study evaluated: (a) the overall effect size of disasters on PTS symptoms; and examined (b) the magnitude of relationships between post-disaster PTS symptoms and pre-existing aspects of the child (i.e., age, gender, gender by age interaction), aspects of the disaster and disaster experience (i.e., proximity to disaster, peritraumatic distress, disaster type, death toll, personal loss), and aspects related to study methodology (i.e., measurement, type of comparison groups, informant, assessment period).

It was hypothesized that across the literature, disasters would be associated with an overall effect on PTS symptoms in youth. Regarding pre-existing aspects of the child, it was hypothesized that girls would exhibit greater PTSD symptoms than boys, and that there would be a Gender by Age interaction, such that the effect of gender would be greater in older youth. Regarding characteristics of the disaster experience, the child's proximity to the disaster, as well as the death toll of the disaster, were both believed to be associated with PTS symptoms, with youth in closer proximity to the disaster, and youth assessed following disasters of greater death tolls, displaying greater PTS symptoms. It was also hypothesized that peritraumatic distress would be associated with post-disaster PTS, with youth experiencing higher levels of threat and distress at the time of the event reporting greater levels of post-disaster PTS. Additionally, youth who lost a loved one 
were believed to exhibit greater PTS symptoms than youth who did not experience disaster-related loss.

Regarding aspects related to study methodology, it was hypothesized that the effect size documented in within-subjects comparisons would be greater in magnitude than that identified in between-subjects comparisons. Given the loss of power associated with treating outcome variables dichotomously (e.g., diagnosis either present or absent), it was also hypothesized that studies examining PTS in a categorical fashion would yield smaller effects than studies examining PTS in a continuous fashion. It was also hypothesized that the post-disaster timing of assessment would be associated with effect size, with studies assessing youth further in time from the occurrence of the disaster reporting a smaller effect than studies assessing youth closer in time to the occurrence of the disaster.

\section{Research Design and Methods \\ Study Selection Criteria}

Studies published prior to January 1, 2009 that satisfied six selection criteria were included in the meta-analysis. First, the study had to have examined PTSD or PTS symptoms (obtained from either a PTSD measure or diagnostic/clinical interview) after a distinct and identifiable disaster, as defined by Task Force on Psychological Responses of Children to Natural and Man-made Disasters (Vogel \& Vernberg, 1993). This definition characterizes disasters as "events that are relatively sudden, highly disruptive, and timelimited (even though the effects may be longer lasting), and public (affecting children from more than one family)" (Vogel \& Vernberg, 1993). Accordingly, studies examining the effects of war, ongoing political violence, or family violence were not included. 
Studies that examined general behavior problems or non-PTSD psychopathology were also not included. Second, the study had to have included children and adolescents under the age of 18 at the time of the assessment, or in a few cases, children were below age 18 at the time of the disaster (included to examine the long-term impact of disasters). The majority of studies included children older than age 6 , with only a few studies examining youth age 2 and older. Third, the sample size must have been large enough to afford statistical analyses. This excluded case studies, case series, or studies with $n<10$. Fourth, the study must have included quantitative (not just qualitative) analyses. Fifth, the study must have provided specific statistical information, including: means, standard deviations, correlation coefficients, $p$-values, sample size, standard error, variance, odd ratios, chi-squares, or enough data for the authors to obtain additional data to calculate the effect sizes needed for meta-analytic procedures. Lastly, for quality control the study must have undergone the peer-review process (dissertations and data published in book chapters were not included).

A number of strategies were used to identify studies satisfying these criteria. First, computerized searches were conducted in MEDLINE and PsycINFO using the following keywords: disaster(s), brushfire(s), earthquake(s), flood(s), hurricane(s), manmade disaster(s), natural disaster(s), PTSD, terrorism, tornado, trauma, or tsunami(s). These terms were then crossed with adolescent(s), child, children, schoolchildren, and youth. Second, the reference sections of each of the articles found via these computerized searches were reviewed to find additional studies not identified by computerized search. Third, tables of contents for the past two years of the study inclusion frame in journals that typically include studies on youth, trauma, PTSD, and child psychopathology were 
also reviewed to identify other potential studies not included in the other above types of searches (i.e., American Journal of Psychiatry, Archives of General Psychiatry, Behaviour Research and Therapy, British Journal of Psychiatry, Depression and Anxiety, Development and Psychopathology, European Child and Adolescent Psychiatry, Journal of Abnormal Child Psychology, Journal of Abnormal Psychology, Journal of Anxiety Disorders, Journal of the American Academy of Child and Adolescent Psychiatry, Journal of Child Psychology and Psychiatry, Journal of Clinical Child and Adolescent Psychology, Journal of Consulting and Clinical Psychology, Journal of Traumatic Stress, Pediatrics). Finally, a search by author name was conducted using the names of known experts in the area to identify any work not yet included.

\section{Variable Coding}

Eligible studies were reviewed and coded for study, methodological, disaster, and child variables, as well as PTSD and PTS symptoms. Mean age, age range, and percentage of female participants were coded for each study. For gender $\mathrm{X}$ age analyses, studies were sorted into studies of mean age $\geq 12$ years and studies of mean age $<12$ years. Additional coding definitions are described below. Study Methodology Variables

Study methodology characteristics include sample size, as well as a number of categorical codings. Control condition referred to the type of comparison against which PTS in the affected sample was compared, and included five levels: (1) between-subjects post design (i.e., affected sample's post-disaster PTS compared to post-disaster PTS in another sample deemed a priori to be less affected), (2) within-subjects prospective design (i.e., affected sample's post-disaster PTS compared to affected sample's pre- 
disaster PTS; pre-disaster data assessed prior to the disaster), (3) within-subjects retrospective design (i.e., affected sample's post-disaster PTS compared to affected sample's pre-disaster PTS; pre-disaster data assessed post-disaster via retrospective recall), (4) cross-sectional pre-post design (i.e., affected sample's post-disaster PTS compared to pre-disaster PTS in another sample), and (5) within-subjects multiple postdisaster design (i.e., affected sample's post-disaster PTS assessed at multiple postdisaster time-points post-disaster; time-points compared chronologically). Measurement quality for PTS assessment was considered dichotomously: (1) sound methodological quality referred to the use of an established measure (i.e., Childhood PTSD Interview, CHIPS, CPSS, CPTSD-RI, CRIES-13/IES, DISC-V, DPS, DSM-III and DSM-IV criteria, K-SADS, MINI-KID, NWS PTSD, PAPA, PED, PROP, PTSD Checklist, SADS, SCID, SR-PTSD Scale, and TMI) or report of psychometric properties for other measures, and (2) methodological quality unknown, referred to the use of a nonestablished measure without reporting psychometric properties. Informant referred to parent-report, child self-report, teacher-report, or clinician diagnosis. The definition of $\underline{\text { PTS }}$ was classified as categorical (i.e., symptoms present=yes/no, or diagnosis present=yes/no), continuous, and both categorical and continuous.

\section{Disaster and Disaster Exposure Variables}

Proximity to disaster was assessed as the sample's mean distance (in miles) from disaster epicenter. Disaster type was classified as natural (i.e., consequence of a natural hazard becoming a physical event interacting with a human inhabited area) or man-made (i.e., consequences of human intent, negligence, or error). Disasters that included both natural and man-made elements were classified according to the initial origin of the 
disaster. For example, a hurricane leading to a dam break was categorized as a natural disaster because a natural event (hurricane) precipitated the man-made element (dam breaking). Assessment period was classified as one year or less (post-disaster assessment conducted mean of $<365$ days) and more than one year (post-disaster assessment conducted mean of $>365$ days). Disaster-related death toll was classified as $\leq 25$ deaths, 26-100 deaths, 101-1000 deaths, and > 1000 deaths. When disaster-related death toll was not reported in the study, this information was obtained from publically available information provided by the Center for Disease Control (CDC). The percentage of the sample reporting perceived life-threat at the time of event, general/unspecified distress at the time of event, and loss of a family member or friend was recorded for all studies including such data.

\section{Procedure}

\section{Coder Training}

Coders were a clinical psychologist, a doctoral candidate in clinical psychology, and an advanced graduate student in psychology. Training of coders included (a) didactics, (b) practice coding, (c) trained-to-criterion testing, and (d) random, unannounced reliability checks.

Didactic training included a two-hour presentation by the PI of PTSD, PTS, the disasters literature, and the categories to be coded. Handouts summarizing the material were provided to augment training and meetings were held to discuss coding-related issues. Trainees spent five hours together as a group practice coding three studies from the adult disaster literature. These studies were drawn from Rubonis and Bickman's (1991) review of the adult disaster literature, and were selected for their inclusion of 
variables included in the current youth meta-analysis. Coders were then each assigned three studies from the adult literature (again selected for their inclusion of variables included in the current youth meta-analysis) to code independently. Coders were given the same three studies to code and met with the PI to address discrepancies. Coders were then assigned a set of ten studies from the adult disaster literature to code independently. Coders obtained at least $80 \%$ inter-rater reliability on these adult studies and were thus deemed "trained-to-criterion" and prepared to code studies for the current meta-analysis.

Studies included in the present youth meta-analysis were divided among the coders, with a randomly selected $5 \%$ of studies assigned to all three coders. Coders met as a group once per month to address coding-related issues and to prevent potential rater drift. Inter-rater reliability was strong for the overlapping studies (all ICCs $>.80$ )

\section{Data Analysis}

There are two types of models typically used in meta-analysis: fixed-effects (FE) and random-effects (RE) models. FE models assume that studies being analyzed have homogenous population effect sizes. Alternatively, RE models do not make this assumption, but rather assume that the population parameter values will vary from study to study; and are assumed to be a sample of all possible studies that might be conducted or exist on the subject (Field, 2001; Hedges, 1992; Hedges \& Olkin, 1985; Hedges \& Vevea, 1998). RE models were selected over FE models for the present meta-analysis due to several consistent problems with FE models and the advantages of the RE models. First, the FE models, although described as "the rule rather than the exception" throughout the literature by the National Research Council (1992), often lead to inflated Type I error rates and erroneously narrow confidence intervals, overestimating the 
precision of the findings (Hunter \& Schmidt, 2004; Lipsey \& Wilson, 2000). In addition, RE models will have the appropriate 5\% Type I error rate regardless of whether the population parameter values are homogenous or heterogeneous. RE models also offer the opportunity to generalize obtained meta-analytic means to the entire domain of studies in a research area (Hunter \& Schmidt, 2004). Often times, there are theoretical, substantive, or methodological variables that create varied population parameters across studies, keeping the chances of inflating the Type I error rate to a minimum with the use of RE models (Lipsey \& Morgan, 2000; National Research Council, 1992).

Accordingly, RE models have been recommended over FE models as more accurate and realistic, as real-world data are likely to have heterogeneous population effect sizes even in the absence of known moderator variables (Field, 2001). Monte Carlo comparisons of the available FE and RE models suggest the Hunter and Schmidt RE method (2004) tends to provide the most accurate estimates of the pooled population effect sizes when effect sizes are heterogeneous, which is the most common case in metaanalytic practice (Field, 2001). Accordingly, the Hunter and Schmidt's RE effects model (Hunter \& Schmidt, 2004; Schmidt \& Hunter, 1999) was applied to compute each pooled effect size, standard deviation of this pooled effect, and the standard error. To assess the significance of pooled effect sizes, $Z$-scores were calculated for each pooled effect by dividing the pooled effect size by the standard error of that pooled effect. Z-scores express the pooled effect size in terms of standard normal deviations, and a significance value (i.e., the probability of obtaining a $Z$ score of such magnitude by chance) can then be computed. $Z$-scores greater than or equal to 1.645 correspond to significance at $\alpha=0.05 . Z$-scores greater than or equal to 2.33 correspond to significance at $\alpha=0.01$. In 
accordance with Hunter and Schmidt's RE method (2004), the homogeneity of effect sizes were assessed with chi-square statistics, calculated based on the sum of squared errors of the pooled effect size.

As effect sizes are interchangeable, all effects sizes drawn from studies were first converted to $r$ prior to meta-analytic synthesis. Only one estimate of effect size was used per construct per study. This decision allowed the samples to remain independent, rather than using several effect sizes from one study for a construct (e.g., a study using multiple measures of PTS symptoms), which could have created dependent samples and violated the assumptions of statistical analyses (Glass, McGaw, \& Smith, 1981; Rosenthal, 1984). To address this issue, multiple effect sizes for a single construct within single studies were averaged prior to the synthesis with effect sizes from other studies. All pooled correlations were interpreted using Cohen's (1988) guidelines for sample-weighted average correlations effect sizes, including a small effect $(r=.10)$, medium effect $(r=$ $.30)$, and large effect $(r=.50)$.

\section{Potential Publication Bias}

Studies with significant findings are more likely to be submitted and accepted for publication. The "file drawer effect" is the probability that unpublished null findings would eliminate the obtained results (Rosenthal, 1991). Often times, these manuscripts are those in which findings were not significant, methodology quality was lacking, or the author decided to not publish the findings due to a lack in magnitude of the findings (Lipsey \& Wilson, 2000; Rosenthal, 1979). If the studies that do not find differences are not accurately represented in the sample of studies included, publication bias may result. To account for the "file-drawer problem," an Orwin "fail-safe N" (FSN; Orwin 1983) 
was calculated for significant results, which corresponds to the number of null results that would be needed to overturn a significant result (the number of studies would make $p>$ $.05)$. If the FSN is greater than or equal to five times the number of studies in the analysis plus 10 (i.e., $\mathrm{FSN} \geq 5 k+10$ ), the results are considered to be robust against the filedrawer effect (Rosenthal, 1991). 


\section{CHAPTER 3}

RESULTS

\section{Characterizing the Literature}

Applying the study selection search criteria and methods, 96 studies were identified that examined PTSD or PTS symptoms in 74,154 total youth (see Table 1 for characteristics of studies). Of the 96 studies, $73 \%$ ( $k=70$ studies) provided control data against which to compare the PTS of exposed youth. Of these 70 studies, $61.4 \%$ ( $k=43$ studies) included a between-subjects post design (i.e., affected sample's post-disaster PTS compared to post-disaster PTS in another sample deemed a priori to be less affected) and $8.6 \%$ ( $k=6$ studies) included a within-subjects prospective design (i.e., affected sample's post-disaster PTS compared to affected sample's pre-disaster PTS; pre-disaster data assessed prior to the disaster) (groups were not mutually exclusive). Only one study (1.4\%) included a within-subjects retrospective design (i.e., affected sample's postdisaster PTS compared to affected sample's pre-disaster PTS; pre-disaster data assessed post-disaster via retrospective recall). Two studies (2.9\%) utilized a cross-sectional prepost design (i.e., affected sample's post-disaster PTS compared to pre-disaster PTS in another sample). A quarter of the studies $(k=18,25.7 \%)$ included a within-subjects multiple post-disaster design (i.e., affected sample's post-disaster PTS assessed at multiple post-disaster time-points post-disaster; time-points compared chronologically) into their study.

\section{Study Design and Measurement}

Table 2 presents the methodological characteristics of empirical studies examining posttraumatic stress in youth following a disaster. As expected, the number of 
studies examining the effects of disasters on youth increased over time from 1986 to 2008, with only 3 studies prior to 1990 meeting search criteria, and up to 12 studies in 2006 and 2007 meeting search criteria. Of the studies included, over half were conducted in the United States $(52.1 \%, k=50)$, with the next highest number of studies $(k=8,8.3 \%)$ being conducted in Turkey. The majority of studies $(87.5 \%, k=84)$ used in-person methods for data collection. A small number of studies used either telephone $(10.4 \%$, $k=10)$ or mail $(7.3 \%, k=7)$ data collection procedures. The post-disaster assessment period ranged from 3 days (Schuster, Stein, Jaycox, Collins, Marshall, Elliott, et al., 2001) to 17 years (Green, Grace, Vary, Kramer, Gleser, \& Leonard, 1994). The majority of studies were conducted within the first year post-disaster $(67.0 \%, k=63)$, whereas roughly thirty percent of studies were conducted more than twelve months post-disaster $(k=31)$.

Regarding methodological quality, most studies addressed missing data or participant non-response, or at least made reference to non-response as a limitation $(72.6 \%, k=69)$. Roughly $70 \%$ of studies included control data $(k=70)$, and almost $90 \%$ used established measures of PTS or provided psychometric data for non-established measures $(k=84)$. Importantly, only 18 studies $(18.9 \%)$ incorporated multi-method assessment.

Regarding informant, the majority of studies used a child self-report questionnaire $(79.2 \%, k=76)$ to obtain PTS data. A parent-report questionnaire was used in roughly $16 \%$ of studies $(k=15)$ to obtain PTS data. A diagnostic interview with the child was used in roughly $40 \%$ of studies $(k=42)$. Across the measures used to assess child PTS, the most commonly used was the CPTSD-RI and related adaptations $(47.9 \%, k=46)$, 
followed by the CRIES-13/IES $(10.4 \%, k=10)$, the CPSS $(8.3 \%, k=8)$, the PTSS $(7.3 \%$, $k=7), \mathrm{KSADS} / \mathrm{SADS}(6.3 \%, k=6)$. Using these measures, PTSD symptoms were examined most often $(50.0 \%$ of the studies, $k=48)$, followed by examining both PTSD symptoms and diagnosis $(40.6 \%, k=39)$. Roughly ten percent $(k=9)$ used only a diagnosis of PTSD with which to characterize PTS in their study participants.

\section{Characteristics of the Disaster and Disaster Experience}

Table 3 presents the characteristics of disasters and disaster experiences in empirical studies examining posttraumatic stress in youth following a disaster. A wide range of disasters was examined in the studies that met search criteria for the present meta-analysis. A majority of the studies examined youth in the aftermath of natural disasters $(64.6 \%, k=62)$, whereas roughly thirty-five percent were conducted following man-made disasters $(35.4 \%, k=34)$. A total of 38 distinct disasters were examined. Of the disasters studied, the September 11, 2001 attacks were the most examined $(12.5 \%, k=12)$, followed by the 2004 Indian Ocean Tsunamis (7.3\%, $k=7)$, Hurricane Andrew (7.3\%, $k=7)$, Hurricane Katrina $(6.3 \%, k=6)$, and the 1999 Turkey Earthquake $(6.3 \%, k=6)$. The majority of post-disaster youth studies $(66.7 \%, k=64)$ were conducted following earthquakes, hurricanes, or terrorist attacks (see Figure 1).

Across the disasters studied, the disaster-related death toll ranged from 0 to 310,000 people (Mean death toll=17,070.27). Almost half of the studies examined a disaster with a death toll greater than $1000(k=41)$. In contrast, 23.3\% of the studies examined disasters with a death toll less than or equal to $25(k=25)$ (see Table 3$)$. In addition, roughly $40 \%$ of the studies examined whether the children experienced the loss of a family member in the disaster $(39.6 \%, \mathrm{n}=38) ; 30.2 \%$ examined whether children 
experienced the loss of a friend $(k=29)$. Across the subset of studies examining loss, the prevalence of loss of a family member was higher among affected youth (12.29\%) than comparison youth $(0.84 \%)$ (see Figure 2$)$. Similarly, affected youth lost more friends in the disasters $(32.01 \%)$ than did comparison youth $(4.54 \%)$.

Regarding proximity, a higher weighted percentage of affected youth were within one mile of the disaster relative to comparison youth (64.17\% vs. $20.63 \%)$. Similarly, the weighted percentage of comparison youth that were 25 or more miles from the disaster was greater than that of affected youth $(38.39 \%$ vs. $17.17 \%)$.

Regarding peritraumatic distress, only $16.7 \%$ of the studies measured children's perceived threat to self at the time of the event $(k=16)$. General or unspecified distress at the time of the disaster was also assessed in $12.5 \%(k=12)$ of the studies. Within this subset of studies, a weighted percentage of over $40 \%$ of youth in the overall sample, as well as in the affected and comparison samples, reported perceiving threat to self at the time of the disaster. A weighted percentage of roughly $64 \%$ of the affected children reported elevated levels of general or unspecified distress at the time of the disaster, whereas $51 \%$ of the comparison youth reported similar distress (Figure 3).

\section{Characteristics of the Child}

The overall mean age of children assessed across the sample, including disasteraffected and comparison youth, ranged from 3.00 to 25.50 years (Weighted $M_{\text {age }}=12.54$, $\mathrm{SD}=3.19)$. The mean age of disaster-affected youth across the studies ranged from 3.00 to 25.50 years (Weighted $M_{\text {age }}=12.56, \mathrm{SD}=3.45$ ). The mean age of comparison youth across studies ranged from 4.50 to 21.60 years (Weighted $M_{\text {age }}=12.13, \mathrm{SD}=3.99$ ). Gender was evenly distributed across the overall sample ( $51.83 \%$ female), and across the 
affected youth (51.91\% female) and comparison youth (53.34\% female). Forty-eight studies $(50 \%)$ examined associations between gender and youth post-disaster PTS.

\section{Rates of PTSD and PTS}

Elevated rates of probable PTSD pooled across studies, weighted by sample size, were observed in both the affected (13.85\%) and comparison samples (10.38\%; see Figure 4). Similarly, pooled rates of diagnosed PTSD, weighted by sample size, were elevated in both samples $(13.18 \%$ in affected and $11.75 \%$ in comparison samples; see Figure 4). Even greater weighted rates of the PTSD symptom clusters were found among the youth in both samples post-disaster (rates ranging from $28.93 \%$ to $53.27 \%$; see Figure 5). All symptom clusters were near $50 \%$ in the affected sample, including $48.45 \%$ reexperiencing, $47.65 \%$ avoidance, and $48.98 \%$ arousal symptoms. Across studies that broke down PTSD diagnosis by gender, a weighted percentage of roughly $31 \%$ of females met diagnostic criteria for PTSD, whereas roughly $25 \%$ of males met criteria. Similarly, across studies that broke down probable PTSD by gender, a weighted percentage of roughly $15 \%$ of females exhibited probable PTSD, whereas roughly $9 \%$ of males exhibited probable PTSD (see Figure 6).

\section{Analysis of All Effect Sizes}

As recommended by Rosenthal (1995), Table 4 shows a stem-and-leaf plot of computed effect sizes. The modal effect sizes of the distribution are around 0-.1 and around .2-.3, after which a fairly even number of effect sizes cluster around the intervals between .3 and .7. The standard deviation of computed effect sizes (calculated in accordance with Hunter \& Schmidt, 2004) was .18, which is higher than the average variability found in meta-analyses published in Psychological Bulletin from 1997-2002 
(Field, 2005). A chi-square test of homogeneity of effect sizes was highly significant, $\chi^{2}(42)=1127.13, p<.001$.

Across the literature, the overall average effect size of disasters on PTS, weighted in accordance with the Hunter and Schmidt (2004) RE method, was $r=.19\left(\mathrm{SE}_{\mathrm{r}}=.03\right.$, $k=42)$, which corresponds to a significant $z$ score $(z=6.30, p<.0001)$. This is a small to medium effect when evaluated by Cohen's (1988) criterion. File-drawer analysis (Rosenthal, 1995) indicates that 25,831 unpublished null findings would be required to weight this average effect into a non-significant effect [i.e., Failsafe Number $(\mathrm{FSN})=25,831]$.

Across studies that broke PTS down by symptom clusters, small effects were found for disasters on youth re-experiencing, avoidance, and hyperarousal symptoms. The average effect size of disasters on re-experiencing symptoms, weighted in accordance with the Hunter and Schmidt RE method (2004), was $r=.136\left(\mathrm{SE}_{\mathrm{r}}=.048\right.$, $k=12)$, which corresponds to a significant $z$ score $(z=2.82, p<.01 ; \mathrm{FSN}=411)$. Overall there was considerable variability across re-experiencing effect sizes $\left(\chi^{2}(12)=255.91\right.$, $p<.001)$. The average effect size of disasters on avoidance symptoms, weighted in accordance with Hunter and Schmidt RE method (2004), was $r=.115\left(\mathrm{SE}_{\mathrm{r}}=.058, k=15\right)$, which corresponds to a significant $z$ score $(z=1.98, p<.05 ; \mathrm{FSN}=310)$. There was considerable variability across avoidance effect sizes $\left(\chi^{2}(15)=568.62, p<.001\right)$. The average effect size of disasters on hyperarousal symptoms, weighted in accordance with Hunter and Schmidt RE method (2004), was $r=.121\left(\mathrm{SE}_{\mathrm{r}}=.071, k=12\right)$, which corresponds to a significant $z$ score $(z=1.69, p<.10 ; \mathrm{FSN}=140)$. There was considerable variability across avoidance effect sizes $\left(\chi^{2}(12)=673.78, p<.001\right)$. 
Youth PTS Effects and Pre-existing Aspects of the Child

Across studies examining associations between child age and youth post-disaster PTS ( $k=26$; Total $N=24,657)$, there was significant variability across age effects $(\chi-$ $\left.{ }^{2}(26)=545.74, p<.001\right)$ and overall a significant age effect was not found $\left(r=-.05, \mathrm{SD}_{\mathrm{r}}=\right.$ $.156, z=-1.61, p>.10)$. Among studies examining associations between gender and youth post-disaster PTS ( $k=48$; Total $N=41,909)$, a small gender effect was found via the Hunter and Schmidt (2004) RE method $\left(r=.14, \mathrm{SD}_{\mathrm{r}}=.01\right)$, corresponding to a significant $z$ score $(z=9.73, p<.0001 ; \mathrm{FSN}=80,527)$. Table 5 shows a stem-and-leaf plot of computed gender effect sizes. The modal effect size of the distribution is around 0-.2, after which a fairly even number of effect sizes cluster around the intervals between .2 and .4. A test of homogeneity revealed significant variability across gender effect sizes $\left(\chi^{2}(48)=557.54, p<.001\right)$. Gender effects were roughly comparable across samples with mean age less than 12 years $\left[r=.11, \mathrm{SD}_{\mathrm{r}}=.10, z=4.48, p<.0001 ; \mathrm{FSN}=2,123\right.$;

$\left.\chi^{2}(17)=104.64, p<.001\right]$ and samples with mean age greater than or equal to 12 years $[r=$ $\left..15, \mathrm{SD}_{\mathrm{r}}=.10, z=6.96, p<.0001 ; \mathrm{FSN}=11,163 ; \chi^{2}(25)=379.05, p<.001\right]$.

Youth PTS Effects and Aspects of the Disaster and Disaster Exposure Overall PTS effect sizes were comparable across natural $\left(r=.16, \mathrm{SD}_{\mathrm{r}}=.183, z=\right.$ $4.05, p<.001 ; k=23$; Total $N=9,173 ; F S N=2,657)$ and man-made disasters $\left(r=.20, \mathrm{SD}_{\mathrm{r}}=\right.$ $.175, z=5.05, p<.001 ; k=19 ;$ Total $N=23,724 ; F S N=3,383)$. Disaster-related death toll was associated with post-disaster youth PTS. Specifically, whereas there was no significant effect of disasters on youth PTS in disasters of death toll $\leq 25\left(r=.09, \mathrm{SD}_{\mathrm{r}}=\right.$ $.332, z=0.98, p>.05 ; k=12$; Total $N=4,169)$, the effect grew steadily for disasters resulting in 26-100 deaths $\left(r=.12, \mathrm{SD}_{\mathrm{r}}=.100, z=2.40, p<.05 ; k=4\right.$; Total $N=1,251$; 
$F S N=30)$, disasters resulting in 101-999 deaths $\left(r=.19, \mathrm{SD}_{\mathrm{r}}=.186, z=2.65, p<.01 ; k=6\right.$; Total $N=5,978 ; F S N=81)$, and disasters resulting in $\geq 1000$ deaths $\left(r=.22, \mathrm{SD}_{\mathrm{r}}=.120, z\right.$ $=7.76, p<.0001 ; k=19 ;$ Total $N=21,418 ; F S N=8,006)$. This trend is depicted in Figure 7.

Table 6 presents a summary of meta-analytic findings on the effect of child proximity, peritraumatic distress, and disaster-related loss on youth post-disaster PTS. Medium and medium-to-large effect sizes were identified for the overall effects of child proximity to the disaster $(r=.33, p<.0001)$, child perceived threat to self at the time of the disaster $(r=.34, p<.0001)$, and general/unspecified peritraumatic distress at the time of the disaster $(r=.38, p<.0001)$. Disaster-related loss of a loved one or friend had an overall small but significant effect on youth post-disaster PTS $(r=.16, p<.0001)$. There was significant variability across effect sizes for proximity, peritraumatic distress, and loss ( $p$ of all $\chi^{2}$ homogeneity analyses $\left.<.001\right)$.

\section{Youth PTS Effects and Aspects of Study Methodology}

Table 7 presents a summary of meta-analytic findings on the effects of disasters on youth PTS by measurement psychometric quality, informant, study period, and measurement mode. A small-to-moderate effect of disasters was found among studies that used established PTS measures or reported acceptable psychometric properties for non-established measures $(r=.20, p<.0001)$, whereas studies that relied on nonestablished measures and did not report acceptable psychometric properties of these measures did not collectively find a significant effect of disasters on youth PTS ( $p>.05)$. A small-to-moderate effect of disasters was found among studies relying on child-report data $(r=.20, p<.0001)$, whereas studies relying on parent-data did not collectively find a significant effect of disasters $(p>.05)$. Similarly, a small-to moderate effect of disasters 
was found among studies conducted in the first year post-disaster $(r=.20, p<.001)$, whereas studies conducted after the first year post-disaster did not collectively find a significant effect of disasters $(p>.05)$. Effect sizes were comparable across studies that used mono- vs. multi-method assessment. PTS effect sizes were lower across studies that used between-subjects comparisons $\left(r=.19, \mathrm{SD}_{\mathrm{r}}=.18, p<.001\right)$ than across studies that used within-subjects comparisons $\left(r=.31, \mathrm{SD}_{\mathrm{r}}=.15, p<.001\right)$. Effect sizes were comparable across studies that used mono- vs. multi-method assessment, and across studies that treated PTS continuously versus categorically. 


\section{CHAPTER 4}

\section{DISCUSSION}

A sizable body of literature has examined youth PTS symptoms in the aftermath of disasters (see Comer \& Kendall, 2007; La Greca et al., 2002; Lonigan et al., 1994; Shannon et al., 1994; Vogel \& Vernberg, 1993; Weems \& Overstreet, 2008). The present meta-analysis represents the first study to quantitatively synthesize this literature (Total $N$ $=74,154$ youth), summarizing the magnitude of overall associations between disasters and youth PTS, and identifying factors associated with variations in the magnitude of these associations. Despite considerable variability across studies, disasters had a significant effect on youth PTS symptoms (overall $r=.19$, corresponding to a pooled $d$ of .4), falling in the small-to-medium range of magnitude. Importantly, aspects related to pre-existing child characteristics (i.e., gender), the disaster and the child's disaster exposure (i.e., disaster-related death toll, child proximity to disaster, peritraumatic distress, personal loss), and study methodology (timing of assessment) are significantly associated with variation in the magnitude of disaster effects on youth PTS symptoms.

Regarding the impact of aspects of the disaster and the child's disaster exposure, the cause of the disaster (e.g., natural vs. man-made) matters far less than the actual extent of destruction (e.g., death toll), where the child was situated during the destruction (proximity), the child's subjective response at the time of the destruction (perceived

threat to self, general/unspecified distress), and whether they lost a loved one or friend in the event. In fact, proximity and peritraumatic distress evidenced medium-to-large associations with youth PTS. These findings are consistent with Kazdin's (2007) assertion that 
"the source (of disasters)... may not be as critical as the disruption, immediate impact, and alarm caused by the event... Severity, shock, loss, and disruption may be among the key dimensions perhaps, not whether there was a human hand in the planning" (Kazdin, 2007, p. 217).

Regarding pre-existing aspects of the child, gender, but not age, was significantly associated with youth PTS. This finding is consistent with Tolin and Foa's (2006) metaanalytic conclusion on sex differences in PTSD across the lifespan that females are at roughly twice the odds of suffering from PTSD than males $(\mathrm{OR}=1.98$, corresponding to $r=.19)$. At present, it remains unclear whether gender effects are associated with biological (e.g., hormonal differences; Yehuda, 1999) or psychosocial variables (e.g., environmental differences, gender socialization), or some interaction of the two. Although age effects have been among the most consistently examined with regard to post-disaster youth PTS, the present meta-analytic failed to identify a significant age effect. Importantly, Silverman and La Greca (2002) note that few studies have had sufficiently large samples of youth representing wide age ranges to adequately investigate developmental differences. Of note, the gender effect was consistent across youth above and below the age of 12 .

Regarding aspects related to study methodology, how PTS is measured, when PTS is measured, and who provides the data each seem to contribute to the extent to which youth PTS is identified following a disaster. Studies that used established measures of youth PTS (or used non-established measures while providing documentation of favorable psychometric properties) found a significant effect, whereas studies that relied on non-established measures and did not provide psychometric data failed to identify a significant effect. Given the unpredictable nature of disasters, the vast majority of studies 
on disaster-affected youth are initiated post-disaster, and as such, less time is afforded for planning than is afforded in investigations of more predictable phenomena. That said, the present findings underscore the importance of measurement considerations when designing post-disaster research — specifically the importance of using established measures in order to detect youth PTS following disasters.

The timing of assessment was found to affect the strength of association between disasters and youth post-disaster PTS. Studies conducted in the first year post-disaster found a stronger effect of disasters on youth PTS than studies conducted beyond one year post-disaster. The first year post-disaster constitutes what has been referred to as the recoil, post-impact, and initial recovery phases (Silverman \& La Greca, 2002; Valent, 2000), during which time many children are forced to relocate, change schools, and/or cope for the first time with the loss of a loved one. These forms of disaster-related life disruption can, in turn, be associated with increased risk of developing post-disaster PTS (e.g., Comer et al., in press; La Greca et al., 1996). Importantly, although the present study did not find a significant effect of disasters on youth PTS among studies conducted after the first year, there was considerable heterogeneity among these studies. For example, whereas Swenson et al. (1996) failed to find a significant effect on youth PTS 14 months after Hurricane Hugo, Mullett-Hume et al. (2008) found a large effect of the 9/11 World Trade Center attack on PTS among youth after two-and-a-half years. Moreover, elevated rates of disorders other than PTSD (e.g., separation anxiety disorder, depression, and generalized anxiety) have been identified during the extended recovery and reconstruction phase (see La Greca, 2007; Silverman \& La Greca, 2002), 
highlighting the critical importance of conducting long-term follow-up assessments in the aftermath of disasters.

Child-informant data indicated a significant effect of disasters on youth postdisaster PTS, whereas parent-informant data did not. Given that many PTS symptoms are internal phenomena (e.g., intrusive recollections, dreams, feelings of detachment, sense of foreshortened future), PTS may manifest largely beyond parents' awareness. In addition, observable symptoms of PTS may occur only in situations outside of the home (e.g., at school, with friends). Moreover, parents of disaster-affected youth are typically coping with the disaster as well, which may encroach upon their ability to reliably report on their child's symptoms. The present findings suggest that child-provided symptom endorsements are the preferred source of data in the assessment of youth PTS in the aftermath of disaster.

\section{Limitations and Future Directions}

Although the present study documents an overall significant effect of disasters on youth PTS, and the importance of child, disaster, and study variables in determining the magnitude of this effect, a number of limitations warrant comment. First, as with any meta-analysis, the present findings speak to the broader population of disasters of which the available body of literature is representative. Currently, the literature on disasters and youth has disproportionately focused on American youth (roughly 52\% of studies). Importantly, disasters in developing countries are more lethal than disasters in industrialized countries, with disasters killing an average of 300 people in developing countries and disasters killing an average of 44 people in industrialized countries (IFRC, 2004). It is likely that developing countries have lower functioning medical and 
emergency assistance systems, which may result in greater spread of disaster and/or slower response after disaster. Developing countries may also lack early warning systems or other resources that would allow coordinated evacuation efforts, which could mitigate loss of human life (e.g., Pfefferbaum, North et al., 2003). Accordingly, future empirical work is needed to evaluate the impact of disasters on youth PTS in developing regions of the world.

Secondly, although the present analysis evaluated a host of child, disaster, and study variables as they relate to youth PTS, a number of key variables not included in the present analysis may play important roles, as well. Much has been written about the roles of pre-existing psychopathology, prior trauma, child coping resources, social support, repeated disaster-related media exposure, the availability of mental health services, prejudice and discrimination, and parental psychopathology (Comer, Furr, Beidas, Weiner, \& Kendall, 2008; Comer \& Kendall, 2007; Karol et al., 1999; La Greca et al., 1996; Silverman \& La Greca, 2002; Swenson et al., 1996; Weems \& Overstreet, 2008). Regrettably, only a small handful of post-disaster studies have evaluated each of these variables, and there is tremendous variability in how these constructs are measured, and so it is unclear whether studies including these variables can meaningfully synthesized. Although the literatures on these potentially important variables are not yet ready to be meta-analyzed, future post-disaster work needs to systematically incorporate these variables into study. In addition, there is a need to develop more standardized assessments of these constructs so that data across studies can be meaningfully integrated. 
Finally, the present meta-analysis evaluated youth PTS symptoms. Although PTS has been the most consistently studied outcome of disasters in youth, clearly this is just one of many potential outcomes. Other negative outcomes, to name just a few, can include other anxiety disorders, depression, complicated and traumatic grief, externalizing disorders, and academic and social impairments. Resilience as an outcome (Luthar, 2003), and factors that promote resilience, needs to be incorporated into postdisaster research, as well as consideration of posttraumatic growth.

\section{Conclusions}

Historically, the majority of research on the psychological effects of disasters has been conducted with adult samples (see Norris et al., 2002; North, 2007; Rubonis \& Bickman, 1991). Only more recently have the effects of disasters on youth begun to be systematically examined. Early clinical presentations on the effects of disasters on youth relied on descriptive techniques, case study, or very small samples of youth, precluding statistical analysis (Freud \& Burlingham, 1943; Honig, Grace, Lindy, Newman, \& Titchener, 1993; Levy, 1945). Over the past 25 years, increasingly rigorous empirical work with youth samples has paralleled the continued refinement of the Diagnostic and Statistical Manual of Mental Disorders (DSM) categorizations of childhood psychopathology, allowing for greater overlap between children's reactions to disasters and diagnosable childhood disorders (e.g., childhood specifiers of PTSD only began being included in DSM-IV; American Psychiatric Association (APA), 1994).

The present study used meta-analytic methods to aggregate data from more than 74,000 youth to produce a reliable estimate of the association between disasters and youth PTS symptoms. This association fell in the small-to-moderate range of magnitude, 
although there was considerable variability that was explained, in part, by aspects of the disaster, child, and study. Specifically, female gender, high death toll, closer proximity, peritraumatic distress, and personal loss were each associated with increased post-disaster PTS in youth. In the aftermath of disasters, governmental funding agencies and private foundations provide substantial resources for child services following disasters. The present meta-analytic findings can help to inform the optimal allocation of these resources and targeted intervention efforts, as well as the development and refinement of new interventions for youth suffering in the aftermath of disasters. 


\section{REFERENCES}

Achenbach, T.M., McConaughy, S.H., \& Howell, C.T. (1987). Child/adolescent behavioral and emotional problems: Implication of cross-informant correlations for situational specificity, Psychological Bulletin, 101, 213-232.

American Academy of Pediatrics, Work Group on Disasters. (1995). Psychosocial issues for children and families in disasters: A guide for the primary care physician. Retrieved May 27, 2007, from http://www.mentalhealth.org/publications/allpubs/SMA95-3022/default.asp.

American Psychiatric Association. (1994). Diagnostic and statistical manual of mental disorders $\left(4^{\text {th }}\right.$ ed.). Washington, DC: Author.

American Psychiatric Association. (2000). Diagnostic and statistical manual of mental disorders ( $4^{\text {th }}$ ed., Text revised). Washington, DC: Author.

Angold, A., Worthman, C., \& Costello, E.J. (2003). Puberty and depression. In C. Hayward (Ed.), Gender differences at puberty (pp.137-164). New York: Cambridge University Press.

Asarnow, J., Glynn, S., Pynoos, R.S., Nahum, J., Guthrie, D., Cantwell, D., \& Franklin, B. (1999). When the earth stops shaking: Earthquake sequelae among children diagnosed for pre-earthquake psychopathology. Journal of the American Academy of Child and Adolescent Psychiatry, 38, 1016-1023.

Bal, A. (2008). Post-traumatic stress disorder in Turkish child and adolescent survivors three years after the Marmara earthquake. Child and Adolescent Mental Health, 13(3), 134-139. 
Bal, A., \& Jensen, B. (2007). Post-traumatic stress disorder symptom clusters in Turkish child and adolescent trauma survivors. European Child and Adolescent Psychiatry, 16, 449-457.

Barnes, V.A., Treiber, F.A., \& Ludwig, D.A. (2005). African-American adolescents' stress responses after the 9/11/01 terrorist attacks. Journal of Adolescent Health, $36,201-207$.

Bhushan, B., \& Kumar, J. S. (2007). Emotional distress and posttraumatic stress in children surviving the 2004 tsunami. Journal of Loss \& Trauma, 12(3), 245-257.

Bokszczanin, A. (2003). The role of coping strategies and social support in adolescent's well-being after a flood. Polish Psychological Bulletin, 34, 67-72.

Bokszczanin, A. (2007). PTSD symptoms in children and adolescents 28 months after a flood: Age and gender differences. Journal of Traumatic Stress, 20, 347-351.

Bolton, D., O'Ryan, D., Udwin, O., Boyle, S., \& Yule, W. (2000). The long-term psychological effects of a disaster experienced in adolescence: II: General psychopathology. Journal of Child Psychology and Psychiatry, 41, 513-523.

Breton, J., Valla, J., \& Lambert, J. (1993). Industrial disaster and mental health of children and their parents. Journal of the American Academy of Child \& Adolescent Psychiatry, 32(2), 438-445.

Bromet, E.J., Goldgaber, D., Carlson, G., Panina, N., Golovakha, E., Gluzman, S.F., et al. (2000). Children's well-being 11 years after the Chornobyl catastrophe. Archives of General Psychiatry, 57, 563-571.

Bronfenbrenner, U. (1979). The ecology of human development. Cambridge, MA: Harvard University Press. 
Bulut, S., Bulut, S., \& Tayli, A. (2005). The dose of exposure and prevalence rates of posttraumatic stress disorder in a sample of Turkish children eleven months after the 1999 Marmara earthquakes. School Psychology International, 26(1), 55-70.

Catani, C., Jacob, N., Schauer, E., Kohila, M., \& Neuner, F. (2008). Family violence, war, and natural disasters: A study of the effect of extreme stress on children's mental health in Sri Lanka. BMC Psychiatry, 8, 1-10.

Cicchetti, D., \& Cohen, D.J. (1995). Perspectives on developmental psychopathology. In D. Cicchetti \& D.J. Cohen (Eds.), Developmental psychopathology, Vol 1: Theory and methods. Oxford, England: John Wiley \& Sons.

Cohen, J. (1988). Statistical power analysis for the behavioral sciences $\left(2^{\text {nd }}\right.$ ed.). Hillsdale, NJ: Erlbaum.

Comer, J.S., Fan, B., Duarte, C., Wu, P., Musa, G., Mandell, D., Albano, A.M., \& Hoven, C. (in press). Attack-related life disruption and child psychopathology in New York City public schoolchildren 6-months post-9/11. Journal of Clinical Child and Adolescent Psychology.

Comer, J.S., Furr, J.M., Beidas, R.S., Weiner, C. L., Kendall, P.C. (2008). Children and terrorism-related news: Training parents in coping and media literacy. Journal of Consulting and Clinical Psychology, 76, 568-578.

Comer, J.C., \& Kendall, P.C. (2004). A symptom-level examination of parent-child agreement in the diagnosis of anxious youths. Journal of the American Academy of Child and Adolescent Psychiatry, 43, 878-886.

Comer, J.S., \& Kendall, P.C. (2007). Terrorism: The psychological impact on youth. Clinical Psychology: Science and Practice, 14, 179-212. 
Cooper, H.M., \& Rosenthal, R. (1980). Statistical versus traditional procedures for summarizing research findings. Psychological Bulletin, 87, 442-449.

De Los Reyes, A., \& Kazdin, A.E. (2004). Measuring informant discrepancies in clinical child research. Psychological Assessment, 16, 330-334.

Duarte, C.S., Hoven, C.W., Wu, P., Bin, F., Cotel, S., Mandell, D.J., et al. (2006). Posttraumatic stress in children with first responders in their families. Journal of Traumatic Stress, 19, 301-306.

Eksi, A., Braun, K., Ertem-Vehid, H., Peykerli, G., Saydam, R., Toparlak, D., \& Alyanak, B.

(2007). Risk factors for the development of PTSD and depression among child and adolescent victims following of a 7.4 magnitude earthquake. International Journal of Psychiatry in Clinical Practice, 11, 190-199.

Endo, T., Shioiri, T., Toyabe, S., Akazawa, K., \& Someya, T. (2007). Parental mental health affects behavioral changes in children following a devastating disaster: A community survey after the 2004 Niigata-Chuetsu earthquake. General Hospital Psychiatry, 27, 175-176.

Evans, L.G., \& Oehler-Stinnett, J. (2006). Structure and prevalence of PTSD symptomology in children who have experienced a severe tornado. Psychology in the Schools, 43, 283-295.

Field, A.P. (2001). Meta-analysis of correlation coefficients: A Monte-Carlo comparison of fixed- and random-effects methods. Psychological Methods, 6, 161-180.

Field, A.P. (2005). Is the meta-analysis of correlation coefficients accurate when population effect sizes vary? Psychological Methods, 10, 444-467. 
Foa, E.B., Johnson, K.M., Feeny, N.C., \& Treadwell, K.R.H. (2001). The Child PTSD Symptom Scale: A preliminary examination of its psychometric properties. Journal of Clinical Child Psychology, 30, 376-384.

Furr, J.M. (2007). The effects of disasters on youth: A preliminary review submitted to the Temple University Graduate Board in partial fulfillment of the requirements for the doctorate of philosophy. Philadelphia, PA: Temple University

Garrison, C.Z., Bryant, E.S., Addy, C.L., Spurrier, P.G., Freedy, J.R., \& Kilpatrick, D.G. (1995). Posttraumatic stress disorder in adolescents after Hurricane Andrew. Journal of the American Academy of Child and Adolescent Psychiatry, 34, 1193-1201.

Giaconia, R.M., Reinherz, H.Z., Silverman, A.B., Pakiz, B., Frost, A.K., \& Cohen, E. (1995). Traumas and posttraumatic stress disorder in a community population of older adolescents. Journal of the American Academy of Child and Adolescent Psychiatry, 34, 1369-1380.

Giannopoulou, I., Strouthos, M., Smith, P., Dikaiakou, A., Galanopoulou, V., \& Yule, W. (2006). Post-traumatic stress reactions of children and adolescents exposed to the Athens 1999 earthquake. European Psychiatry, 21, 160-166.

Glass, G.V., McGaw, B., \& Smith, M.L. (1981). Meta-analysis in social research. Beverly Hills, CA: Sage Publications.

Goenjian, A.K., Molina, L., Steinberg, A.M., Fairbanks, L.A., Alvarez, M.L., Goenjian, H.A., \& Pynoos, R.S. (2001). Posttraumatic stress and depressive reactions among Nicaraguan adolescents after Hurricane Mitch. American Journal of Psychiatry, 158, 788-794. 
Goenjian, A.K., Pynoos, R.S., Steinberg, A.M., Endres, D., Abraham, K., Geffner, M.E., \& Fairbanks, L.A. (2003). Hypothalamic-pituitary-adrenal activity among Armenian adolescents with PTSD symptoms. Journal of Traumatic Stress, 16, 319-323.

Goenjian, A.K., Pynoos, R.S., Steinberg, A.M., Najarian, L.M., Asarnow, J.R., Karayan, I., et al. (1995). Psychiatric comorbidity in children after the 1988 earthquake in Armenia. Journal of the American Academy of Child \& Adolescent Psychiatry, $34,1174-1184$

Goenjian, A. K., Walling, D., Steinberg, A. M. , Karayan, I., Najarian, L. M., \& Pynoos, R. (2005). A prospective study of posttraumatic stress and depressive reactions among treated and untreated adolescents 5 years after a catastrophic disaster. American Journal of Psychiatry, 162, 2302 - 2308.

Green, B.L., Grace, M.C., Vary, M.G., Kramer, T.L., Gleser, G.C., \& Leonard, A.C. (1994). Children of disaster in the second decade: A 17-year follow-up of Buffalo Creek survivors. Journal of the American Academy of Child and Adolescent Psychiatry, 33, 71-79.

Green, B.L., Korol, M.S., Grace, M.C., Vary, M.G., Leonard, A.C., Gleser, G.C., \& Smitson-Cohen, S. (1991). Children and disaster: Age, gender, and parental effects of PTSD symptoms. Journal of the American Academy of Child and Adolescent Psychiatry, 30, 945-951.

Grills, A.E., \& Ollendick, T.H. (2003). Multiple informant agreement and the Anxiety Disorders Interview Schedule for Parents and Children. Journal of the American Academy of Child and Adolescent Psychiatry, 42, 30-40. 
Groome, D., \& Soureti, A. (2004). Post-traumatic stress disorder and anxiety symptoms in children exposed to the 1999 Greek earthquake. British Journal of Psychology, 95(3), 387-397.

Hamada, R.S., Kameoka, V., Yanagida, E., \& Chemtob, C.M. (2003). Assessment of elementary school children for disaster-related posttraumatic stress disorder symptoms: The Kauai Recovery Index. Journal of Nervous and Mental Disease, 191, 268-272

Handford, H.A., Dickerson, S., Mattison, R.E., Humphrey, F.J., II., Bagnato, S., Bixler, E.O., \& Kales, J.D. (1986). Child and parent reaction to the Three Mile Island nuclear accident. Journal of the American Academy of Child Psychiatry, 25, 346356.

Hedges, L.V. (1992). Meta-analysis. Journal of Educational Statistics, 17, 279-296.

Hedges, L.V., \& Olkin, I. (1985). Statistical methods for meta-analysis. San Diego, CA: Academic Press.

Hedges, L.V., \& Vevea, J.L. (1998). Fixed- and random-effects models in meta-analysis. Psychological Methods, 3, 486-504.

Hensley, L., \& Varela, R. E. (2008). PTSD symptoms and somatic complaints following Hurricane Katrina: The roles of trait anxiety and anxiety sensitivity. Journal of Clinical Child and Adolescent Psychology, 37(3), 542-552.

Hoven, C.W., Duarte, C.S., Lucas, C.P., Wu, P., Mandell, D.J., Goodwin, R.D. et al. (2005). Psychopathology among New York City public school children 6 months after September 11. Archives of General Psychiatry, 62, 545-552. 
Hsu, C., Chong, M., Yang, P., \& Yen, C. (2002). Posttraumatic stress disorder among adolescent earthquake victims in Taiwan. Journal of the American Academy of Child \& Adolescent Psychiatry, 41(7), 875-881.

Hunter, J.E., \& Schmidt, F.L. (2004). Methods of meta-analysis: Correcting error and bias in research findings ( $2^{\text {nd }}$ ed.). Thousand Oaks, CA: Sage Publications. International Federation of Red Cross and Red Crescent Societies. (1998). World disasters report. New York: Oxford University Press.

International Federation of Red Cross and Red Crescent Societies. (2004). World disasters report. New York: Oxford University Press.

Joseph, S. A., Brewin, C. R., Yule, W., \& Williams, R. (1993). Causal attributions and post-traumatic stress in adolescents. Journal of Child Psychology and Psychiatry, $34(2), 247-253$.

Kar, N., \& Bastia, B. K. (2006). Post-traumatic stress disorder, depression and generalized anxiety disorder in adolescents after a natural disaster: A study of comorbidity. Clinical Practice and Epidemiology in Mental Health, 2, 17-24.

Kar, N., Mohapatra, P. K., Nayak, K. C., Pattanaik, P., Swain, S. P., \& Kar, H. C. (2007). Post-traumatic stress disorder in children and adolescents one year after a super-cyclone in Orissa, India: Exploring cross-cultural validity and vulnerability factors. BMC Psychiatry, 7, 1-9.

Kazdin, A.E. (2007). Child reactions to terrorism: Cautions and next steps for research. Clinical Psychology: Science and Practice, 14, 213-218. 
Kiliç, E. Z., Özgüven, H. D., \& Sayil, I. (2003). The psychological effects of parental mental health on children experiencing disaster: The experience of Bolu earthquake in Turkey. Family Process, 42(4), 485-495.

Kolaitis, G., Kotsopoulos, J., Tsiantis, J., Haritaki, S., Rigizou, F., Zacharaki, L., et al. (2003). Posttraumatic stress reactions among children following the Athens earthquake of September 1999. European Child \& Adolescent Psychiatry, 12(6), 273-280.

Koplewicz, H.S., Vogel, J.M., Solanto, M.V., Morrissey, R.F., Alonso, C.M., Abikoff, H., et al.. (2002). Child and parent response to the 1993 World Trade Center bombing. Journal of Traumatic Stress, 15, 77-85.

Korol, M., Green, B.L., \& Gleser, G.C. (1999). Children's responses to a nuclear waste disaster: PTSD symptoms and outcome prediction. Journal of the American Academy of Child and Adolescent Psychiatry, 38, 368-375.

La Greca, A.M. (2007). Understanding the psychological impact of terrorism on youth: Moving beyond posttraumatic stress disorder. Clinical Psychology: Science and Practice, 14, 219-223.

La Greca, A.M., \& Silverman, W.K. (2006). Children and adolescents, disasters and terrorism. In P.C. Kendall (Ed.), Child and adolescent therapy: Cognitivebehavioral procedures ( $3^{\text {rd }}$ Ed.). New York: Guilford.

La Greca, A.M., Silverman, W.K., Vernberg, E.M., \& Prinstein, M.J. (1996). Symptoms of posttraumatic stress in children after Hurricane Andrew: A prospective study. Journal of Consulting and Clinical Psychology, 64, 712-723. 
La Greca, A.M., Silverman, W.K., Vernberg, E.M., \& Roberts, M.C. (2002). Helping children cope with disasters and terrorism. Washington, D.C.: American Psychological Association.

La Greca, A.M., Silverman, W.K., \& Wasserstein, S.B. (1998). Children’s predisaster functioning as a predictor of posttraumatic stress following Hurricane Andrew. Journal of Consulting and Clinical Psychology, 66, 883-892.

Lack, C. W., \& Sullivan, M. A. (2008). Attributions, coping, and exposure as predictors of long-term posttraumatic distress in tornado-exposed children. Journal of Loss \& Trauma, 13(1), 72-84.

Laor, N., Wolmer, L., Kora, M., Yucel, D., Spirman, S., \& Yazgan, Y. (2002). Posttraumatic, dissociative and grief symptoms in Turkish children exposed to the 1999 earthquakes. Journal of Nervous and Mental Disease, 190(12), 824-832.

Lengua, L.J., Long, A.C., \& Meltzoff, A.N. (2006). Pre-attack stress-load, appraisals, and coping in children's responses to the 9/11 terrorist attacks. Journal of Child Psychology and Psychiatry, 47, 1219-1227.

Lengua, L.J., Long, A.C., Smith, K.I., \& Meltzoff, A.N. (2005). Pre-attack symptomatology and temperament as predictors of children's responses to the September 11 terrorist attacks. Journal of Child Psychology and Psychiatry, 46, $631-645$.

Levant, R.F. (2002). Psychology responds to terrorism. Professional Psychology: Research and Practice, 33, 507-509. 
Levine, L.J., Whalen, C.K., Henker, B., \& Jamner, L.D. (2005). Looking back on September 11, 2001: Appraised impact and memory for emotions in adolescent and adults. Journal of Adolescent Research, 20, 497-523.

Lipsey, M.W., \& Wilson, D.B. (2000). Practical meta-analysis. Applied Social Research Methods Series (Vol. 49). Thousand Oaks, CA: Sage Publications.

Liu, A., Tan, H., Zhou, J., Li, S., Yang, T., Sun, Z., Wen, S. W. (2007). Brief screening instrument of posttraumatic stress disorder for children and adolescents 7-15 years of age. Child Psychiatry and Human Development, 38(3), 195-202.

Lonigan, C.J., Anthony, J.L., \& Shannon, M.P. (1998). Diagnostic efficacy of posttraumatic symptoms in children exposed to disaster. Journal of Clinical Child Psychology, 27, 255-267.

Lonigan, C.J., Shannon, M.P., Taylor, C.M., Finch, A.J., \& Sallee, F.R. (1994). Children exposed to disaster: II. Risk factors for the development of post-traumatic symptomatology. Journal of the American Academy of Child and Adolescent Psychiatry, 33, 94-105.

Luthar, S.S. (2003). Resilience and vulnerability: Adaptation in the context of childhood adversities. New York: Cambridge University Press.

March, J. S., Amaya-Jackson, L., Terry, R., \& Costanzo, P. (1997). Posttraumatic symptomatology in children and adolescents after an industrial fire. Journal of the American Academy of Child \& Adolescent Psychiatry, 36, 1080-1088.

Marsee, M. A. (2008). Reactive aggression and posttraumatic stress in adolescents affected by Hurricane Katrina. Journal of Clinical Child and Adolescent Psychology, 37(3), 519-529. 
McDermott, B. M., Lee, E. M., Judd, M., \& Gibbon, P. (2005). Posttraumatic stress disorder and general psychopathology in children and adolescents following a wildfire disaster. The Canadian Journal of Psychiatry, 50(3), 137-143.

McDermott, B.M., \& Palmer, L.J. (2002). Postdisaster emotional distress, depression and event-related variables: Findings across child and adolescent developmental stages. Australian and New Zealand Journal of Psychiatry, 36, 754-761.

McFarlane, A. C. (1987). Posttraumatic phenomena in a longitudinal study of children following a natural disaster. Journal of the American Academy of Child \& Adolescent Psychiatry, 26(5), 764-769.

Mirzamani, M., Mohammadi, M. R., \& Ali Besharat, M. (2006). Post-traumatic stress disorder symptoms of children following the occurrence of Tehran City Park Disaster. Journal of Psychology: Interdisciplinary and Applied, 140(3), 181-186.

Mohr, W. (2002). Understanding children in crisis: The developmental ecological framework. In W.N. Zubenko, \& J.A. Capozzoli (Eds.), Children and disasters: A practical guide to healing and recovery (pp. 72-84). New York: Oxford University Press.

Mullett-Hume, E., Anshel, D., Guevara, V., \& Cloitre, M. (2008). Cumulative trauma and posttraumatic stress disorder among children exposed to the 9/11 World Trade Center attack. American Journal of Orthopsychiatry, 78(1), 103-108.

Nader, K., Pynoos, R., Fairbanks, L., \& Frederick, C. (1990). Children’s PTSD reactions one year after a sniper attack at their school. American Journal of Psychiatry, 147, 1526-1530. 
Najarian, L. M., Goenjian, A. K., Pelcovitz, D., Mandel, F., et al. (1996). Relocation after a disaster: Posttraumatic stress disorder in Armenia after the earthquake. Journal of the American Academy of Child \& Adolescent Psychiatry, 35(3), 374-383

National Research Council. (1992). Combining information: Statistical issues and opportunities for research. Washington, DC: National Academy of Sciences Press.

Neuner, F., Schauer, E., Catani, C., Ruf, M., \& Elbert, T. (2006). Post-tsunami stress: A study of posttraumatic stress disorder in children living in three severely affected regions in Sri Lanka. Journal of Traumatic Stress, 19, 339-347.

North, C.S. (2007). Psychiatric and psychological issues in survivors of major disasters. In A.E. Dell Orto, \& P.W. Power (Eds.), The psychological and social impact of illness and disability (5th ed., pp. 214-229). New York: Springer Publishing Co.

North, C.S., \& Pfefferbaum, B. (2002). Research on the mental health effects of terrorism. JAMA, 288, 633-636.

Orwin, R.G. (1983). A fail-safe $N$ for effect size in meta-analysis. Journal of Educational Statistics, 8, 157-159.

Pfefferbaum, B., Nixon, S., Krug, R., Tivis, R., Moore, V., Brown, J., et al. (1999). Clinical needs assessment of middle and high school students following the 1995 Oklahoma City bombing. American Journal of Psychiatry, 156, 1069-1074.

Pfefferbaum, B., Nixon, S., Tucker, P., Tivis, R., Moore, V., Gurwitch, R.H., et al. (1999). Posttraumatic stress responses in bereaved children after the Oklahoma City bombing. Journal of the American Academy of Child and Adolescent Psychiatry, 38, 1372-1379. 
Pfefferbaum, B., \& North. C.S. (2008). Research with children exposed to disasters. International Journal of Methods in Psychiatric Research, 17, S49-S56.

Pfefferbaum, B., North, C.S., Doughty, D.E., Gurwitch, R.H., Fullerton, C.S., \& Kyula, J. (2003). Posttraumatic stress and functional impairment in Kenyan children following the 1998 American Embassy bombing. American Journal of Orthopsychiatry, 73, 133-140.

Pfefferbaum, B., North, C.S., Doughty, D.E., Pfefferbaum, R.L, Dumont, C.E., Pynoos, R.S., et al. (2006). Trauma, grief, and depression in Nairobi children after the 1998 bombing of the American Embassy. Death Studies, 30, 561-577.

Pfefferbaum, B., Sconzo, G.M., Flynn, B.W., Kearns, L.J., Doughty, D.E., Gurwitch, R.H., et al. (2003). Case finding and mental health services for children in the aftermath of the Oklahoma City bombing. Journal of Behavioral Health Services and Research, 30, 215-227.

Pfefferbaum, B., Seale, T. W., McDonald, N. B., Brandt, E. N., Jr., Rainwater, S. M., Maynard, B. T., et al. (2000). Posttraumatic stress two years after the Oklahoma City bombing in youths geographically distant from the explosion. Psychiatry: Interpersonal and Biological Processes, 63(4), 358-370.

Pfefferbaum, B., Stuber, J., Galea, S., \& Fairbrother, G. (2006). Panic reactions to terrorist attacks and probable posttraumatic stress disorder in adolescents. Journal of Traumatic Stress, 19, 217-228.

Pina, A. A., Villalta, I. K., Ortiz, C. D., Gottschall, A. C., Costa, N. M., \& Weems, C. F. (2008). Social support, discrimination, and coping as predictors of posttraumatic 
stress reactions in youth survivors of Hurricane Katrina. Journal of Clinical Child and Adolescent Psychology, 37(3), 564-574.

Prinstein, M.J., La Greca, A.M., Vernberg, E.M., \& Silverman, W.K. (1996). Children’s coping assistance: How parents, teachers, and friends help children cope after a natural disaster. Journal of Clinical Child Psychology, 25, 463-475.

Proctor, L., Fauchier, A., Oliver, P. H., Ramos, M. C., Rios, M. A., \& Margolin, G. (2007). Family context and young children's responses to earthquakes. Journal of Child Psychology and Psychiatry, 48, 941-949.

Pullins, L. G., McCammon, S. L., Lamson, A. S., Wuensch, K. L., \& Mega, L. (2005). School-based post-flood screening and evaluation: Findings and challenges in one community. Stress, Trauma and Crisis: An International Journal, 8(4), 229-249.

Pynoos, R., Frederick, C., Nader, K., Arroyo, W., Steinberg, A., Eth, S., et al. (1987). Life threat and posttraumatic stress in school-age children. Archives of General Psychiatry, 44, 1057-1063.

Pynoos, R., Goenjian, A., Tashjian, M., Karakashian, M., Manjikian, R., Manoukian, G., et al. (1993). Post-traumatic stress reactions in children after the 1988 Armenian earthquake. British Journal of Psychiatry, 163, 239-247.

Pynoos, R.S., Nader, K., Frederick, C., Gonda, L., et al. (1987). Grief reactions in school age children following a sniper attack at school. Israel Journal of Psychiatry and Related Sciences, 24, 53-63.

Rosenthal, R. (1979). The "file-drawer problem" and tolerance for null results. Psychological Bulletin, 86, 638-641. 
Rosenthal, R. (1984). Meta-analytic procedures for social research. Applied Social Research Methods Series (Vol. 6). Beverly Hills, CA: Sage Publications.

Rosenthal, R. (1991). Meta-analytic procedures for social research. London: Sage Publications.

Rosenthal, R. (1995). Writing meta-analytic reviews. Psychological Bulletin, 118, 183192.

Rosenthal, R., \& Rosnow, R.L. (1991). Essentials of behavioral research: Methods and data analysis (2 ${ }^{\text {nd }}$ Edition). New York: McGraw Hill.

Roussos, A., Goenjian, A.K., Steinberg, A.M., Sotiropoulou, C., Kakaki, M., Kabakos, C., et al. (2005). Posttraumatic stress and depressive reactions among children and adolescents after the 1999 earthquake in Ano Liosia, Greece. American Journal of Psychiatry, 162, 530-537.

Rubonis, A.V., \& Bickman, L. (1991). Psychological impairment in the wake of disaster: The disaster-psychopathology relationship. Psychological Bulletin, 109, 384-399. Russoniello, C. V., Skalko, T. K., O'Brien, K., McGhee, S. A., Bingham-Alexander, D., \& Beatley, J. (2002). Childhood posttraumatic stress disorder and efforts to cope after Hurricane Floyd. Behavioral Medicine, 28(2), 61-70.

Sahin, N.H., Batıgun, A. D., \& Yılmaz, B. (2007). Psychological symptoms of Turkish children and adolescents after the 1999 earthquake: Exposure, gender, location, and time duration. Journal of Traumatic Stress, 20, 335-345.

Saylor, C.F., Cowart, B.L., Lipovsky, J.A., Jackson, C., \& Finch, A.J. (2003). Media exposure to September 11: Elementary school students' experiences and posttraumatic symptoms. American Behavioral Scientist, 46, 1622-1642. 
Scheeringa, M. S., \& Zeanah, C. H. (2008). Reconsideration of harm's way: Onsets and comorbidity patterns of disorders in preschool children and their caregivers following Hurricane Katrina. Journal of Clinical Child and Adolescent Psychology, 37(3), 508-518.

Schuster, M.A., Stein, B.D., Jaycox, L.H., Collins, R.L., Marshall, G.N., Elliott, M.N., et al. (2001). A national survey of stress reactions after the September 11, 2001 terrorist attacks. New England Journal of Medicine, 345, 1507-1512.

Schwarz, E.D., \& Kowalski, J.M. (1991). Malignant memories: PTSD in children and adults after a school shooting. Journal of the American Academy of Child and Adolescent Psychiatry, 30, 936-944.

Scrimin, S., Axia, G., Capello, F., Moscardino, U., Steinberg, A.M., \& Pynoos, R.S. (2006). Posttraumatic reactions among injured children and their caregivers 3 months after the terrorist attack in Beslan. Psychiatry Research, 141, 333-336.

Shannon, M. P., Lonigan, C. J., Finch, A. J., \& Taylor, C. M. (1994). Children exposed to disaster: I. Epidemiology of post-traumatic symptoms and symptom profiles. Journal of the American Academy of Child \& Adolescent Psychiatry, 33(1), 8093.

Shaw, J.A., Applegate, B., \& Schorr, C. (1996). Twenty-one-month follow-up study of school-age children exposed to Hurricane Andrew. Journal of the American Academy of Child and Adolescent Psychiatry, 35, 359-364.

Shaw, J. A., Applegate, B., Tanner, S., Perez, D., Rothe, E., Campo-Bowen, A., et al. (1995). Psychological effects of hurricane Andrew on an elementary school 
population. Journal of the American Academy of Child \& Adolescent Psychiatry, $34,1185-1192$.

Silverman, W.K., \& La Greca, A.M. (2002). Children experiencing disasters: Definitions, reactions, and predictors of outcomes. In A.M. La Greca, W.K. Silverman, E.M. Vernberg, \& M.C. Roberts (Eds.), Helping Children Cope with Disasters and Terrorism (pp. 11-33). Washington, DC: American Psychological Association. Spell, A. W., Kelley, M. L., Wang, J., Self-Brown, S., Davidson, K. L., Pellegrin, A., et al. (2008). The moderating effects of maternal psychopathology on children's adjustment post-Hurricane Katrina. Journal of Clinical Child and Adolescent Psychology, 37(3), 553-563.

Stein, B.D., Jaycox, L.H., Elliott, M.N., Collins, R., Berry, S., Marshall, G.N., et al., (2004). The emotional and behavioral impact of terrorism on children: Results from a national survey. Applied Developmental Sciences, 8, 184-194.

Stuber, J., Fairbrother, G., Galea, S., Pfefferbaum, B., Wilson-Genderson, M., \& Vlahov, D. (2002). Determinants of counseling for children in Manhattan after the September 11 attacks. Psychiatric Services, 53, 815-822.

Swenson, C.C., Saylor, C.F., Powell, M.P., Stokes, S.J., Foster, K.Y., \& Belter, R.W. (1996). Impact of a natural disaster on preschool children: Adjustment 14 months after a hurricane. American Journal of Orthopsychiatry, 66, 122-130.

Terr, L.C., Bloch, D.A., Michel, B.A., Shi, H., Reinhardt, J.A., \& Metayer, S. (1997). Children's thinking in the wake of Challenger. American Journal of Psychiatry, 154, 744-751. 
Thienkura, W., Cardozo, B.L., Chakkraband, M.L.S., Guadamuz, T.E., Pengjuntr, W., Tantipiwatanaskul, P., et al. (2006). Symptoms of posttraumatic stress disorder and depression among children in tsunami-affected areas in southern Thailand. Journal of the American Medical Association, 296, 549-559.

Tolin, D.F., \& Foa, E.B. (2006). Sex differences in trauma and posttraumatic stress disorder: A quantitative review of 25 years of research. Psychological Bulletin, $132,959-992$.

Valent, P. (2000). Disaster syndrome. In G. Fink (Ed.), Encyclopedia of Stress (Vol. 1, pp. 706-709). San Diego, CA: Academic Press.

Vernberg, E.M., La Greca, A.M., Silverman, W.K., \& Prinstein, M.J. (1996). Prediction of posttraumatic stress symptoms in children after Hurricane Andrew. Journal of Abnormal Psychology, 105, 237-248.

Vernberg, E.M., \& Varela, R.E. (2001). Posttraumatic stress disorder: A developmental perspective. In M.W. Vasey \& M.R. Dadds (Eds.), The developmental psychopathology of anxiety (386-406). New York: Oxford University Press.

Vijayakumar, L., Kannan, G. K., \& Daniel, S. J. (2006). Mental health status in children exposed to Tsunami. International Review of Psychiatry, 18(6), 507-513.

Vila, G., Porche, L., \& Mouren-Simeoni, M. (1999). An 18-month longitudinal study of posttraumatic disorders in children who were taken hostage in their school. Psychosomatic Medicine, 61, 746-754.

Vila, G., Witowski, P., Tondini, M. C., Perez-Diaz, F., Mouren-Simeoni, M. C., \& Jouvent, R. (2001). A study of posttraumatic disorders in children who 
experienced an industrial disaster in the Briey region. European Child \& Adolescent Psychiatry, 10(1), 10-18.

Vogel, J.M., \& Vernberg, E.M. (1993). Children's psychological responses to disaster. Journal of Clinical Child Psychology, 22, 464-484.

Weems, C.F., \& Overstreet, S. (2008). Child and adolescent mental health research in the context of Hurricane Katrina: An ecological-needs-based perspective and introduction to the special section. Journal of Clinical Child and Adolescent Psychology, 37, 487-494.

Weems, C.F., Pina, A.A., Costa, N.M., Watts, S.E., Taylor, L.K., \& Cannon, M.F. (2007). Predisaster trait anxiety and negative affect predict posttraumatic stress in youths after Hurricane Katrina. Journal of Consulting and Clinical Psychology, $75,154-159$.

Whalen, C.K., Henker, B., King, P.S., Jamner, L.D., \& Levine, L. (2004). Adolescents react to the events of September 11, 2001: Focused versus ambient impact. Journal of Abnormal Child Psychology, 32, 1-11.

Wickrama, K. A. S., \& Kaspar, V. (2007). Family context of mental health risk in Tsunami-exposed adolescents: Findings from a pilot study in Sri Lanka. Social Science \& Medicine, 64(3), 713-723.

Wolmer, L., Laor, N., Dedeoglu, C., Siev, J., \& Yazgan, Y. (2005). Teacher-mediated intervention after disaster: A controlled three-year follow-up of children's functioning. Journal of Child Psychology and Psychiatry, 46, 1161-1168.

Yehuda, R. (1999). Biological factors associated with susceptibility to posttraumatic stress disorder. Canadian Journal of Psychiatry, 44, 34-39. 
Yule, W., Bolton, D., Udwin, O., Boyle, S., O’Ryan, D., \& Nurrish, J. (2000). The longterm psychological effects of a disaster experienced in adolescence: I. The incidence and course of PTSD. Journal of Child Psychology and Psychiatry, 41, 503-512. 
Table 1. Characteristics of Empirical Studies Examining Posttraumatic Stress in Youth Following a Disaster

\begin{tabular}{|c|c|c|c|c|c|}
\hline Study & Disaster & $\mathbf{N}$ & $\begin{array}{l}\text { Age range } \\
\text { (in years) }^{\mathrm{a}}\end{array}$ & Assessment Period(s) & Informant \\
\hline $\begin{array}{l}\text { Asarnow, Glynn, Pynoos, } \\
\text { Nahum, Guthrie, et al. } \\
\text { (1999) }\end{array}$ & $\begin{array}{l}\text { 1/17/94 Northridge, } \\
\text { CA earthquake }\end{array}$ & 49 & $8.59-18.60$ & 1.22 years post-disaster & Child \\
\hline Bal (2008) & $\begin{array}{l}1999 \text { Marmara } \\
\text { Earthquake in Turkey }\end{array}$ & 293 & $8-15$ & 3 years post-disaster & Child \\
\hline Bal \& Jensen (2007) & $\begin{array}{l}1999 \text { Marmara } \\
\text { Earthquake in Turkey }\end{array}$ & 293 & $8-15$ & 3 years post-disaster & Child \\
\hline $\begin{array}{l}\text { Barnes, Treiber, \& Ludwig } \\
(2005)\end{array}$ & $\begin{array}{l}\text { 9/11/2001 WTC and } \\
\text { Pentagon attacks }\end{array}$ & 406 & $M=16.1$ & 3 months post-disaster & Adolescents \\
\hline Bhushan \& Kumar (2007) & 2004 Tsunami & 130 & $10-16$ & 1 year post-disaster & Child \\
\hline Bokszczanin (2002) & 1997 Flood in Poland & 335 & $11-20$ & 20 months post-disaster & Child \\
\hline Bokszczanin (2007) & 1997 Flood in Poland & 533 & $11-21$ & 28 months post-disaster & Child \\
\hline
\end{tabular}


Table 1 cont.

\begin{tabular}{|c|c|c|c|c|c|}
\hline $\begin{array}{l}\text { Bolton, O’Ryan, Udwin, } \\
\text { Boyle, \& Yule (2000) }\end{array}$ & $\begin{array}{l}\text { 10/21/88 Jupiter ship } \\
\text { sinking in Greek waters }\end{array}$ & 294 & $\begin{array}{l}\text { 11-18 at time } \\
\text { of disaster }\end{array}$ & $\begin{array}{l}5 \text { months post-disaster; } 5.7 \\
\text { to } 7.9 \text { years post-disaster }\end{array}$ & Child \\
\hline $\begin{array}{l}\text { Breton, Valla, \& Lambert } \\
\text { (1993) }\end{array}$ & $\begin{array}{l}\text { Montreal Industrial } \\
\text { Fire disaster }\end{array}$ & 86 & $6-11$ & 12-15 months post-disaster & Child \\
\hline $\begin{array}{l}\text { Bromet, Goldgaber, Carlson, } \\
\text { Panina, Golovakha, et al. } \\
\text { (2000) }\end{array}$ & $\begin{array}{l}1986 \text { Chornobyl } \\
\text { nuclear power plant } \\
\text { accident }\end{array}$ & 300 & $10-12$ & 11 years post-disaster & $\begin{array}{l}\text { Child, } \\
\text { Parents, } \\
\text { Teachers }\end{array}$ \\
\hline Brown \& Goodman (2005) & $\begin{array}{l}\text { 9/11/2001 WTC and } \\
\text { Pentagon attacks }\end{array}$ & 83 & $8-18$ & $\begin{array}{c}\text { Mean }=321 \text { days }(\mathrm{SD}=127) \\
\text { post-disaster }\end{array}$ & $\begin{array}{l}\text { Child, } \\
\text { Parents }\end{array}$ \\
\hline Bulut, Bulut, \& Tayli (2005) & $\begin{array}{l}1999 \text { Marmara } \\
\text { Earthquake in Turkey }\end{array}$ & 300 & Unknown & 11 months post-disaster & Child \\
\hline $\begin{array}{l}\text { Catani, Jacob, Schauer, } \\
\text { Kohila, \& Neuner (2008) }\end{array}$ & 2004 Tsunami & 296 & $9-15$ & Not reported & Child \\
\hline
\end{tabular}


Table 1 cont.

\begin{tabular}{|c|c|c|c|c|c|}
\hline $\begin{array}{l}\text { Duarte, Hoven, Wu, Bin, } \\
\text { Mandell, Nagsawa, et al. } \\
\text { (2006) }\end{array}$ & $\begin{array}{l}\text { 9/11/2001 WTC and } \\
\text { Pentagon attacks }\end{array}$ & 8236 & $9-21$ & 6 months post-disaster & Child \\
\hline $\begin{array}{l}\text { Eksi, Braun, Ertem-Vehid, } \\
\text { Peykerli, Saydam, Toparlak, } \\
\text { \& Alyankak (2007) }\end{array}$ & $\begin{array}{l}1999 \text { Earthquake in } \\
\text { Turkey }\end{array}$ & 160 & $9-18$ & $\begin{array}{c}6-20 \text { (mean 16.3) weeks } \\
\text { post-disaster }\end{array}$ & Child \\
\hline $\begin{array}{l}\text { Endo, Shioiri, Toyabe, } \\
\text { Akazawa, \& Someya (2007). }\end{array}$ & $\begin{array}{l}2004 \text { Niigata-Chuetsu } \\
\text { earthquake }\end{array}$ & 756 & $\begin{array}{l}\text { Preschool and } \\
\text { School-aged } \\
\text { children }\end{array}$ & $\begin{array}{l}\text { Pre-disaster; immediately } \\
\text { post-disaster; } 1 \text { week, } 1 \\
\text { month, and } 5 \text { months post- } \\
\text { disaster }\end{array}$ & Parents \\
\hline $\begin{array}{l}\text { Evans \& Oehler-Stinnett } \\
\text { (2006) }\end{array}$ & $\begin{array}{l}\text { May } 1999 \text { tornado in } \\
\text { Stroud and Mulhall, } \\
\text { OK }\end{array}$ & 152 & $6-12$ & 1 year post-tornado & Child \\
\hline $\begin{array}{l}\text { Foa, Johnson, Feeny, \& } \\
\text { Treadwell (2001) }\end{array}$ & $\begin{array}{l}1994 \text { Northridge, CA } \\
\text { earthquake }\end{array}$ & 75 & $8-15$ & 2 years post-disaster & Child \\
\hline
\end{tabular}


Table 1 cont.

\begin{tabular}{|c|c|c|c|c|c|}
\hline $\begin{array}{l}\text { Garrison, Bryant, Addy, } \\
\text { Spurrier, Freedy, \& } \\
\text { Kilpatrick (1995) }\end{array}$ & Hurricane Andrew & 400 & $12-17$ & 6 months post-disaster & $\begin{array}{c}\text { Adolescents, } \\
\text { Parents }\end{array}$ \\
\hline $\begin{array}{l}\text { Giannopoulou, Strouthos, } \\
\text { Smith, Dikaiakou, } \\
\text { Galanopoulou, \& Yule } \\
\text { (2006) }\end{array}$ & $\begin{array}{l}1999 \text { Athens } \\
\text { earthquake }\end{array}$ & 2036 & $9-17$ & 6-7 months post-disaster & Child \\
\hline $\begin{array}{l}\text { Goenjian, Molina, Steinberg, } \\
\text { Fairbanks, Alvarez, et al. } \\
\text { (2001) }\end{array}$ & $\begin{array}{l}\text { Hurricane Mitch in } \\
\text { Central America }\end{array}$ & 158 & $M=13$ & 6 months post-disaster & Child \\
\hline $\begin{array}{l}\text { Goenjian, Pynoos, Steinberg, } \\
\text { Endres, Abraham, Geffner, } \\
\text { \& Fairbanks (2003) }\end{array}$ & $\begin{array}{l}1988 \text { Armenian } \\
\text { earthquake }\end{array}$ & 64 & $M=14$ & 6.5 years post-disaster & Child \\
\hline $\begin{array}{l}\text { Goenjian, Pynoos, Steinberg, } \\
\text { Najarian, Asarnow, Karayan, } \\
\text { et al. (1995). }\end{array}$ & $\begin{array}{l}1988 \text { Armenian } \\
\text { earthquake }\end{array}$ & 218 & $M=12.97$ & 1.5 years post-disaster & Child \\
\hline
\end{tabular}


Table 1 cont.

\begin{tabular}{|c|c|c|c|c|c|}
\hline $\begin{array}{l}\text { Goenjian, Walling, } \\
\text { Steinberg, Karayan, } \\
\text { Najarian, \& Pynoos (2005). }\end{array}$ & $\begin{array}{l}1988 \text { Armenian } \\
\text { (Spitak) earthquake }\end{array}$ & 125 & & $\begin{array}{l}5 \text { years post-disaster; } 1.5 \\
\text { years post-disaster } \\
\text { comparison }\end{array}$ & Child \\
\hline $\begin{array}{l}\text { Green, Grace, Vary, Kramer, } \\
\text { Gleser, \& Leonard (1994). }\end{array}$ & $\begin{array}{l}1972 \text { Buffalo Creek } \\
\text { dam collapse }\end{array}$ & 99 & $\begin{array}{l}\text { Aged 2-15 at } \\
\text { time of } \\
\text { disaster }\end{array}$ & 17 years post-disaster & $\begin{array}{c}\text { Children } \\
\text { (now adults) }\end{array}$ \\
\hline $\begin{array}{l}\text { Green, Korol, Grace, Vary, } \\
\text { Leonard, et al. (1991). }\end{array}$ & $\begin{array}{l}1972 \text { Buffalo Creek } \\
\text { dam collapse }\end{array}$ & 179 & $\begin{array}{l}\text { Age 2-15 at } \\
\text { time of } \\
\text { disaster }\end{array}$ & 1.5 - 2 years-post disaster & $\begin{array}{l}\text { Child, } \\
\text { Parents }\end{array}$ \\
\hline Groome \& Soureti (2004) & 1999 Greek Earthquake & 178 & $9-17$ & 5 months post-disaster & Child \\
\hline $\begin{array}{l}\text { Hamada, Kameoka, } \\
\text { Yanagida, \& Chemtob } \\
\text { (2003) }\end{array}$ & 1992 Hurricane Iniki & 3732 & $6-15$ & 26 months post-disaster & Child \\
\hline
\end{tabular}


Table 1 cont.

\begin{tabular}{|c|c|c|c|c|c|}
\hline $\begin{array}{l}\text { Hamada, Kameoka, } \\
\text { Yanagida, \& Chemtob } \\
\text { (2007). }\end{array}$ & 1992 Hurricane Iniki & 4,184 & $6-15$ & $\begin{array}{c}\text { Study 1: } 3-4 \text { months post- } \\
\text { disaster } \\
\text { Study 2: } 26 \text { months post- } \\
\text { disaster }\end{array}$ & Child \\
\hline $\begin{array}{l}\text { Handford, Mayes, Mattison, } \\
\text { Humphrey, Bagnato, et al. } \\
\text { (1986). }\end{array}$ & $\begin{array}{l}1979 \text { Three Mile Island } \\
\text { (TMI) nuclear accident }\end{array}$ & 35 & $6-19$ & 1.5 years post-disaster & $\begin{array}{l}\text { Child, } \\
\text { Parents }\end{array}$ \\
\hline Hensley, \& Varela (2008) & Hurricane Katrina & 302 & $10-15$ & 5-8 months post-disaster & Child \\
\hline $\begin{array}{l}\text { Hoven, Duarte, Lucas, Wu, } \\
\text { Mandell, et al. (2005) }\end{array}$ & $\begin{array}{l}\text { 9/11/2001 WTC and } \\
\text { Pentagon attacks }\end{array}$ & 8236 & $9-21$ & 6 months post-disaster & Child \\
\hline $\begin{array}{l}\text { Hsu, Chong, Yang, \& Yen } \\
\text { (2002) }\end{array}$ & $\begin{array}{l}1999 \text { Taiwan } \\
\text { Earthquake }\end{array}$ & 323 & $12-14$ & 6 weeks post-disaster & Child \\
\hline $\begin{array}{l}\text { Joseph, Brewin, Yule, \& } \\
\text { Williams (1993) }\end{array}$ & $\begin{array}{l}1988 \text { Jupiter Ship } \\
\text { sinking }\end{array}$ & 16 & $13-15$ & $\begin{array}{c}5 \text { months, } 1 \text { year post- } \\
\text { disaster }\end{array}$ & Child \\
\hline
\end{tabular}


Table 1 cont.

\begin{tabular}{|c|c|c|c|c|c|}
\hline Kar \& Bastia (2006) & $\begin{array}{l}1999 \text { Super-cyclone in } \\
\text { Orissa, India }\end{array}$ & 108 & $M=14.28$ & 14 months post-disaster & Child \\
\hline $\begin{array}{l}\text { Kar, Mohapatra, Nayak, } \\
\text { Pattanaik, Swain, \& Kar } \\
\text { (2007) }\end{array}$ & $\begin{array}{l}1999 \text { Super-cyclone in } \\
\text { Orissa, India }\end{array}$ & 447 & $7-17$ & 1 year post-disaster & $\begin{array}{l}\text { Child, } \\
\text { Parents, } \\
\text { Teacher }\end{array}$ \\
\hline $\begin{array}{l}\text { Kiliç, Özgüven, \& Sayil } \\
\text { (2003) }\end{array}$ & $\begin{array}{l}1999 \text { Turkish } \\
\text { Earthquake (Bolu) }\end{array}$ & 49 & $7-14$ & 3 months post-disaster & Child \\
\hline $\begin{array}{l}\text { Kolaitis, Kotsopoulos, } \\
\text { Tsiantis, Haritaki, Rigizou, } \\
\text { Zacharaki, et al. (2003) }\end{array}$ & 1999 Greek Earthquake & 163 & $M=11.05$ & 6 months post-disaster & Child \\
\hline $\begin{array}{l}\text { Koplewicz, Vogel, Solanto, } \\
\text { Morrissey, Alonso, et al. } \\
\text { (2002) }\end{array}$ & 1993 WTC bombing & 22 & Grades $2,3,5$ & $\begin{array}{c}\text { 3-months; 9- months post } \\
\text { disaster }\end{array}$ & $\begin{array}{l}\text { Child, } \\
\text { Parents }\end{array}$ \\
\hline $\begin{array}{l}\text { Korol, Green, \& Gleser } \\
\text { (1999). }\end{array}$ & $\begin{array}{l}1984 \text { Nuclear waste } \\
\text { disaster in Fernald, } \mathrm{OH}\end{array}$ & 180 & $7-15$ & 5 years post-disaster & $\begin{array}{l}\text { Child, } \\
\text { Parents }\end{array}$ \\
\hline
\end{tabular}


Table 1 cont.

\begin{tabular}{|c|c|c|c|c|c|}
\hline $\begin{array}{l}\text { La Greca, Silverman, } \\
\text { Vernberg, \& Prinstein } \\
\text { (1996). }\end{array}$ & Hurricane Andrew & 442 & Grades 3-5 & $\begin{array}{l}\text { 3-months, 7-months, 10- } \\
\text { months months post-disaster }\end{array}$ & Child \\
\hline $\begin{array}{l}\text { La Greca, Silverman, \& } \\
\text { Wasserstein (1998). }\end{array}$ & Hurricane Andrew & 92 & Grades 4-6 & $\begin{array}{l}15 \text { months pre-disaster; } 3 \text { - } \\
\text { months, } 7 \text {-months post- } \\
\text { disaster }\end{array}$ & $\begin{array}{c}\text { Child, Peers, } \\
\text { Teachers }\end{array}$ \\
\hline Lack, \& Sullivan (2008) & 2001 Tornado & 102 & $8-12$ & 13 months post-disaster & Child \\
\hline $\begin{array}{l}\text { Laor, Wolmer, Kora, Yucel, } \\
\text { Spirman, \& Yazgan (2002) }\end{array}$ & $\begin{array}{l}1999 \text { Marmara } \\
\text { Earthquake in Turkey }\end{array}$ & 303 & $M=8.52$ & 4-5 months post-disaster & Child \\
\hline $\begin{array}{l}\text { Lengua, Long, \& Meltzoff } \\
\text { (2006) }\end{array}$ & $\begin{array}{l}\text { 9/11/2001 WTC and } \\
\text { Pentagon attacks }\end{array}$ & 147 & $9.13-13.65$ & $\begin{array}{l}1,2 \text { years pre-disaster; } \\
1 \text { month post-disaster }\end{array}$ & $\begin{array}{l}\text { Child, } \\
\text { Parents }\end{array}$ \\
\hline $\begin{array}{l}\text { Lengua, Long, Smith, \& } \\
\text { Meltzoff (2005) }\end{array}$ & $\begin{array}{l}\text { 9/11/2001 WTC and } \\
\text { Pentagon attacks }\end{array}$ & 207 & $9.13-13.65$ & $\begin{array}{l}\text { 1, } 2 \text { years pre-disaster; } 1 \\
\text { month, } 6 \text { months post- } \\
\text { disaster }\end{array}$ & $\begin{array}{l}\text { Child, } \\
\text { Parents }\end{array}$ \\
\hline
\end{tabular}


Table 1 cont.

\begin{tabular}{|c|c|c|c|c|c|}
\hline $\begin{array}{l}\text { Levine, Whalen, Henker, \& } \\
\text { Jamner (2005) }\end{array}$ & $\begin{array}{l}\text { 9/11/2001 WTC and } \\
\text { Pentagon attacks }\end{array}$ & 81 & $14-18$ & $\begin{array}{c}3 \text { months; } 8 \text { months post- } \\
\text { disaster }\end{array}$ & $\begin{array}{c}\text { Adolescents, } \\
\text { Parents }\end{array}$ \\
\hline $\begin{array}{l}\text { Liu, Tan, Zhou, Li, Yang, } \\
\text { Sun, \& Wen (2007) }\end{array}$ & $\begin{array}{l}\text { 1998-1999 Hunan } \\
\text { Floods in China }\end{array}$ & 6703 & $7-15$ & 8-15 months post-disaster & Child \\
\hline $\begin{array}{l}\text { Lonigan, Anthony, \& } \\
\text { Shannon (1998) }\end{array}$ & Hurricane Hugo & 5687 & $9-19$ & 3 months post-disaster & Child \\
\hline McFarlane (1987) & $\begin{array}{l}1983 \text { Australian } \\
\text { Bushfire }\end{array}$ & 808 & $M=8.2$ & $\begin{array}{c}2 \text { months, } 8 \text { months, } 26 \\
\text { months post-disaster }\end{array}$ & $\begin{array}{l}\text { Child, } \\
\text { Parents, } \\
\text { Teacher }\end{array}$ \\
\hline $\begin{array}{l}\text { March, Amaya-Jackson, } \\
\text { Terry, \& Costanzo (1997). }\end{array}$ & $\begin{array}{l}1991 \text { Imperial foods } \\
\text { chicken processing } \\
\text { plant explosion and fire } \\
\text { in Hamlet, NC }\end{array}$ & 1,019 & $10-16$ & 9 months post-disaster & $\begin{array}{c}\text { Child, } \\
\text { Teachers }\end{array}$ \\
\hline Marsee (2008) & Hurricane Katrina & 166 & $14-18$ & 15-18 months post-disaster & Child \\
\hline $\begin{array}{l}\text { McDermott, Lee, Judd, \& } \\
\text { Gibbon (2005) }\end{array}$ & $\begin{array}{l}2003 \text { Australian } \\
\text { Wildfire }\end{array}$ & 222 & $8-18$ & 6 months post-disaster & $\begin{array}{l}\text { Child, } \\
\text { Parents }\end{array}$ \\
\hline
\end{tabular}


Table 1 cont.

\begin{tabular}{|c|c|c|c|c|c|}
\hline McDermott \& Palmer (2002) & $\begin{array}{l}\text { 5-day Bushfire in New } \\
\text { South Wales, } 1994\end{array}$ & 2379 & $8-19$ & 6 months post-disaster & Child \\
\hline $\begin{array}{l}\text { Mirzamani, Mohammadi, \& } \\
\text { Ali Besharat (2006) }\end{array}$ & $\begin{array}{l}1992 \text { Tehran City Park } \\
\text { Boat Sinking Disaster }\end{array}$ & 19 & $13-15$ & 18 months post-disaster & Child \\
\hline $\begin{array}{l}\text { Mullett-Hume, Anshel, } \\
\text { Guevara, \& Cloitre (2008) }\end{array}$ & 9/11 WTC attack & 204 & $12-16$ & 2.5 years post-disaster & Child \\
\hline $\begin{array}{l}\text { Nader, Pynoos, Fairbanks, \& } \\
\text { Frederick (1990). }\end{array}$ & $\begin{array}{l}1984 \text { Sniper attack on } \\
\text { elementary school } \\
\text { playground }\end{array}$ & 100 & & 14 months post-disaster & Child \\
\hline $\begin{array}{l}\text { Najarian, Goenjian, } \\
\text { Pelcovitz, Mandel, et al. } \\
\text { (1996) }\end{array}$ & $\begin{array}{l}1988 \text { Armenian } \\
\text { Earthquake }\end{array}$ & 74 & $11-14$ & 2.5 years post-disaster & Child \\
\hline $\begin{array}{l}\text { Neuner, Schauer, Catani, } \\
\text { Ruf, \& Elbert (2006) }\end{array}$ & 2004 Tsunami & 264 & $8-14$ & 3- to 4- weeks post-disaster & Child \\
\hline $\begin{array}{l}\text { Pfefferbaum, Nixon, Tucker, } \\
\text { Tivis, Moore, et al. (1999) }\end{array}$ & $\begin{array}{l}1995 \text { Oklahoma City } \\
\text { bombing }\end{array}$ & 3218 & Grades 6-12 & 7 weeks post-disaster & Child \\
\hline
\end{tabular}


Table 1 cont.

\begin{tabular}{|c|c|c|c|c|c|}
\hline $\begin{array}{l}\text { Pfefferbaum, North, } \\
\text { Doughty, Gurwitch, } \\
\text { Fullerton, \& Kyula (2003) }\end{array}$ & $\begin{array}{l}1998 \text { American } \\
\text { Embassy bombing in } \\
\text { Nairobi, Kenya }\end{array}$ & 562 & $9-17$ & 8-14 months post-disaster & Child \\
\hline $\begin{array}{l}\text { Pfefferbaum, North, } \\
\text { Doughty, Pfefferbaum, } \\
\text { Dumont, Pynoos, et al. } \\
\text { (2006) }\end{array}$ & $\begin{array}{l}1998 \text { American } \\
\text { Embassy bombing in } \\
\text { Nairobi, Kenya }\end{array}$ & 156 & $10-12$ & 8-14 months post-disaster & Child \\
\hline $\begin{array}{l}\text { Pfefferbaum, Sconzo, Flynn, } \\
\text { Kearns, Doughty, et al. } \\
\text { (2003) }\end{array}$ & $\begin{array}{l}1995 \text { Oklahoma City } \\
\text { bombing }\end{array}$ & 2720 & Grades 6-12 & 7 weeks post-disaster & Child \\
\hline $\begin{array}{l}\text { Pfefferbaum, Seale, } \\
\text { McDonald, Brandt, Jr., } \\
\text { Rainwater, Maynard, et al. } \\
(2000)\end{array}$ & $\begin{array}{l}1995 \text { Oklahoma City } \\
\text { bombing }\end{array}$ & 69 & Grade $=6$ & 2 years post-disaster & Child \\
\hline $\begin{array}{l}\text { Pfefferbaum, Stuber, Galea, } \\
\text { \& Fairbrother (2006) }\end{array}$ & $\begin{array}{l}\text { 9/11/2001 WTC and } \\
\text { Pentagon attacks }\end{array}$ & 161 & $12-17$ & 6-9 months post-disaster & $\begin{array}{c}\text { Adolescents; } \\
\text { Parents }\end{array}$ \\
\hline
\end{tabular}


Table 1 cont.

\begin{tabular}{|c|c|c|c|c|c|}
\hline $\begin{array}{l}\text { Pina, Villalta, Ortiz, } \\
\text { Gottschall, Costa, \& Weems } \\
\text { (2008) }\end{array}$ & Hurricane Katrina & 46 & $M=11.43$ & 6-7 months post-disaster & Child \\
\hline $\begin{array}{l}\text { Prinstein, La Greca, } \\
\text { Vernberg, \& Silverman } \\
\text { (1996). }\end{array}$ & Hurricane Andrew & 506 & Grades 3-5 & 7 months post-disaster & $\begin{array}{l}\text { Child, } \\
\text { Parents, } \\
\text { Teachers, } \\
\text { Peers }\end{array}$ \\
\hline $\begin{array}{l}\text { Proctor, Fauchier, Oliver, } \\
\text { Ramos, Rios, \& Margolin } \\
\text { (2007) }\end{array}$ & $\begin{array}{l}1994 \text { Northridge } \\
\text { Earthquake }\end{array}$ & 117 & $\begin{array}{c}\text { 4-5 at time of } \\
\text { disaster }\end{array}$ & $\begin{array}{c}\text { Pre-earthquake; } 8.74 \text { months } \\
\text { post-earthquake }\end{array}$ & Parents \\
\hline $\begin{array}{l}\text { Pullins, McCammon, } \\
\text { Lamson, Wuensch, Mega } \\
\text { (2005) }\end{array}$ & Hurricane Floyd & 612 & $5-19$ & 3.5 months post-disaster & Child \\
\hline $\begin{array}{l}\text { Pynoos, Goenjian, Tashjian, } \\
\text { Karakashian, et al. (1993) }\end{array}$ & $\begin{array}{l}1988 \text { Armenian } \\
\text { Earthquake }\end{array}$ & 231 & $8-16$ & 1.5 years post-disaster & Child \\
\hline
\end{tabular}


Table 1 cont.

\begin{tabular}{|c|c|c|c|c|c|}
\hline $\begin{array}{l}\text { Pynoos, Nader, Frederick, } \\
\text { Gonda, et al. (1987). }\end{array}$ & $\begin{array}{l}1984 \text { Sniper attack on } \\
\text { elementary school } \\
\text { playground }\end{array}$ & 251 & $6-13$ & 1 year post-disaster & Child \\
\hline $\begin{array}{l}\text { Roussos, Goenjian, } \\
\text { Steinberg, Sotiropoulou, } \\
\text { Kakaki, Kabakos, et al. } \\
(2005) \text {. }\end{array}$ & $\begin{array}{l}1999 \text { Earthquake in } \\
\text { Ano Liosia, Greece }\end{array}$ & 1937 & & 3 months post-disaster & Child \\
\hline $\begin{array}{l}\text { Russoniello, Skalko, } \\
\text { O'Brien, McGhee, Bingham- } \\
\text { Alexander, \& Beatley } \\
\text { (2002) }\end{array}$ & Hurricane Floyd & 150 & $9-12$ & 6 months post-disaster & Child \\
\hline $\begin{array}{l}\text { Sahin, Batigun, \& Yilmaz } \\
\text { (2007) }\end{array}$ & $\begin{array}{l}1999 \text { Earthquake in } \\
\text { Turkey }\end{array}$ & 1260 & $6-11$ & $\begin{array}{l}\text { 5-8 months post-disaster; 8- } \\
11 \text { months post-disaster } \\
\text { comparison }\end{array}$ & Parents \\
\hline $\begin{array}{l}\text { Saylor, Cowart, Lipovsky, } \\
\text { Jackson, \& Finch, Jr. (2003) }\end{array}$ & $\begin{array}{l}\text { 9/11/2001 WTC and } \\
\text { Pentagon attacks }\end{array}$ & 179 & $5-11$ & 1 month post-disaster & $\begin{array}{l}\text { Child, } \\
\text { Parents }\end{array}$ \\
\hline
\end{tabular}


Table 1 cont.

\begin{tabular}{|c|c|c|c|c|c|}
\hline Scheeringa, \& Zeanah (2008) & Hurricane Katrina & 70 & $3.1-6.8$ & 5 months post-disaster & Child \\
\hline $\begin{array}{l}\text { Schuster, Stein, Jaycox, } \\
\text { Collins, Marshall, Elliott, et } \\
\text { al. (2001) }\end{array}$ & $\begin{array}{l}\text { 9/11/2001 WTC and } \\
\text { Pentagon attacks }\end{array}$ & 170 & $5-18$ & 3-5 days post-disaster & $\begin{array}{l}\text { Child, } \\
\text { Parents }\end{array}$ \\
\hline $\begin{array}{l}\text { Schwarz, \& Kowalski } \\
\text { (1991). }\end{array}$ & $\begin{array}{l}\text { Shooting attack on } \\
\text { elementary school and } \\
2^{\text {nd }} \text { grade classroom }\end{array}$ & 64 & $5-14$ & 6-14 months post-disaster & $\begin{array}{c}\text { Child, School } \\
\text { Personnel }\end{array}$ \\
\hline $\begin{array}{l}\text { Scrimin, Axia, Capello, } \\
\text { Moscardino, Steinberg, \& } \\
\text { Pynoos (2006). }\end{array}$ & $\begin{array}{l}2004 \text { terrorist attack, } 3 \text { - } \\
\text { day hostage takeover, } \\
\text { and terrorist mine } \\
\text { explosion on School } \\
\text { Number } 1 \text { in Beslan, } \\
\text { Russia }\end{array}$ & 22 & $6-14$ & 3 months post-disaster & $\begin{array}{l}\text { Child, } \\
\text { Parents }\end{array}$ \\
\hline $\begin{array}{l}\text { Shannon, Lonigan, Finch, \& } \\
\text { Taylor (1994) }\end{array}$ & Hurricane Hugo & 5687 & $9-19$ & 3 months post-disaster & Child \\
\hline
\end{tabular}


Table 1 cont.

\begin{tabular}{|c|c|c|c|c|c|}
\hline $\begin{array}{l}\text { Shaw, Applegate, \& Schorr } \\
\text { (1996). }\end{array}$ & Hurricane Andrew & 30 & $7-13$ & $\begin{array}{c}\text { 8-months, } 21 \text {-months post- } \\
\text { disaster }\end{array}$ & $\begin{array}{l}\text { Child, } \\
\text { Teachers }\end{array}$ \\
\hline $\begin{array}{l}\text { Shaw, Applegate, Tanner, } \\
\text { Perez, Rothe, Campo- } \\
\text { Bowen, \& Lahey (1995). }\end{array}$ & Hurricane Andrew & 144 & $6-11$ & $\begin{array}{c}\text { 8-weeks, 32- weeks post- } \\
\text { disaster }\end{array}$ & $\begin{array}{l}\text { Child, } \\
\text { Teachers }\end{array}$ \\
\hline $\begin{array}{l}\text { Spell, Kelley, Wang, Self- } \\
\text { Brown, Davidson, Pellegrin, } \\
\text { Palcic, et al. (2008) }\end{array}$ & Hurricane Katrina & 260 & $8-16$ & $\begin{array}{c}\text { 89-219 days (mean = } 162 \\
\text { days) post-disaster }\end{array}$ & Child \\
\hline $\begin{array}{l}\text { Swenson, Saylor, Powell, } \\
\text { Stokes, Foster, \& Belter } \\
\text { (1996). }\end{array}$ & $\begin{array}{l}\text { Hurricane Hugo } \\
\text { (Charleston, NC) }\end{array}$ & 331 & $2-10$ & 14 months post-disaster & $\begin{array}{c}\text { Parents } \\
\text { (Mothers) }\end{array}$ \\
\hline $\begin{array}{l}\text { Terr, Bloch, Michel, Shi, } \\
\text { Reinhardt, \& Metayer (1997) }\end{array}$ & $\begin{array}{l}1986 \text { Challenger } \\
\text { spacecraft explosion }\end{array}$ & 153 & & $\begin{array}{l}\text { 5-7 weeks post-disaster; } 14 \\
\text { months post-disaster }\end{array}$ & $\begin{array}{c}\text { Child, } \\
\text { Adolescents }\end{array}$ \\
\hline
\end{tabular}


Table 1 cont .

\begin{tabular}{|c|c|c|c|c|c|}
\hline $\begin{array}{l}\text { Thienkura, Cardozo, } \\
\text { Chakkraband, Guadamuz, } \\
\text { Pengjuntr, } \\
\text { Tantipiwatanaskul, et al. } \\
\text { (2006). }\end{array}$ & 2004 Tsunami & 417 & $7-14$ & $\begin{array}{l}\text { 2-months, 9- months post- } \\
\text { disaster }\end{array}$ & Child \\
\hline $\begin{array}{l}\text { Vernberg, LaGreca, } \\
\text { Silverman, \& Prinstein } \\
\text { (1996) }\end{array}$ & Hurricane Andrew & 568 & Grades 3-5 & 3 months post-disaster & Child \\
\hline $\begin{array}{l}\text { Vijayakumar, Kannan, \& } \\
\text { Daniel (2006) }\end{array}$ & 2004 Tsunami & 230 & $11-14$ & 11 months post-disaster & Child \\
\hline $\begin{array}{l}\text { Vila, Porche, \& Mouren- } \\
\text { Simeoni (1999) }\end{array}$ & $\begin{array}{l}2005 \text { hostage and bomb } \\
\text { threat event of } \\
\text { elementary school } \\
\text { classroom near Paris, } \\
\text { France }\end{array}$ & 47 & $6-9.5$ & $\begin{array}{c}2 \text { months; } 4 \text { months; } 7 \\
\text { months; } 18 \text { months post- } \\
\text { attack }\end{array}$ & Child \\
\hline
\end{tabular}


Table 1 cont.

\begin{tabular}{|c|c|c|c|c|c|}
\hline $\begin{array}{l}\text { Vila, Witowski, Tondini, } \\
\text { Perez-Diaz, Mouren- } \\
\text { Simeoni, \& Jouvent (2001) }\end{array}$ & $\begin{array}{l}\text { Industrial disaster in } \\
\text { Briey region }\end{array}$ & 93 & $4-13$ & 6-7 months post-disaster & $\begin{array}{l}\text { Child, } \\
\text { Parents }\end{array}$ \\
\hline $\begin{array}{l}\text { Weems, Pina, Costa, Watts, } \\
\text { Taylor, \& Cannon (2007). }\end{array}$ & Hurricane Katrina & 52 & $M=11.35$ & $\begin{array}{c}17 \text { months pre-disaster; 6-7 } \\
\text { months post-disaster }\end{array}$ & Child \\
\hline $\begin{array}{l}\text { Whalen, Henker, King, } \\
\text { Jamner, \& Levine (2004) }\end{array}$ & $\begin{array}{l}\text { 9/11/2001 WTC and } \\
\text { Pentagon attacks }\end{array}$ & 171 & $14.8-18.7$ & $\begin{array}{c}\text { 1,2, } 3 \text { years pre-disaster; } 2 \text { - } \\
5 \text { months post-disaster }\end{array}$ & Adolescents \\
\hline Wickrama \& Kaspar (2007) & 2004 Tsunami & 325 & $12-19$ & 4 months post-disaster & Child \\
\hline $\begin{array}{l}\text { Wolmer, Laor, Dedeoglu, } \\
\text { Siev, \& Yazgan (2005) }\end{array}$ & $\begin{array}{l}1999 \text { Earthquake in } \\
\text { Turkey }\end{array}$ & 287 & $9-17$ & 3.5 years post-disaster & $\begin{array}{l}\text { Child, } \\
\text { Parents, } \\
\text { Teachers }\end{array}$ \\
\hline $\begin{array}{l}\text { Yule, Bolton, Udwin, Boyle, } \\
\text { O’Ryan, \& Nurrish (2000) }\end{array}$ & $\begin{array}{l}\text { 10/21/88 Jupiter ship } \\
\text { sinking in Greek waters }\end{array}$ & 304 & $\begin{array}{l}11-18 \text { at time } \\
\text { of disaster }\end{array}$ & $\begin{array}{l}5 \text { months post-disaster; } 5.7 \\
\text { to } 7.9 \text { years post-disaster }\end{array}$ & Child \\
\hline
\end{tabular}

Note: See methods section for description of study search criteria; WTC $=$ World Trade Center; PTSD $=$ posttraumatic stress disorder

${ }^{a}$ When age range not given, mean age or grade range provided 
Table 2. Methodological Characteristics of Empirical Studies Examining Posttraumatic Stress in Youth

Following a Disaster $(k=96$; Total $\mathrm{N}=74,154)$

\begin{tabular}{lcc}
\hline Variable & $\boldsymbol{k}$ & \% of studies \\
\hline Control condition & 26 & 27.1 \\
None & 43 & 44.8 \\
Between-subjects Post & 6 & 6.3 \\
Within-subjects Prospective & 1 & 1.0 \\
Within-subjects Retrospective & 2 & 2.1 \\
Cross-sectional Pre-Post & 18 & 18.8 \\
Within-subjects Multiple Post & & 87.5 \\
Data Collection & 84 & 10.4 \\
In Person & 10 & 7.3 \\
Telephone & 70.9 \\
Mail & & \\
Methodological rigor & & \\
Addressed missing data & 70 & \\
\hline
\end{tabular}


Table 2 cont.

Established PTS measure/reported

psychometrics

Multi-method assessment

PTS measurement type/informant

Child self-report questionnaire

Child diagnostic interview

42

Parent-report questionnaire

15

Parent diagnostic interview

8

Teacher report

Frequently used PTS measures

CPTSD-RI and related measures

CRIES-13/IES and related measures

10

10.4

CPSS

8

PTSS

KSADS/SADS

PTS variable 
Table 2 cont.

Diagnosis

9

9.4

Both

39

40.6

Time since disaster

$\leq 1$ year

63

65.0

$>1$ year

31

33.0

Note: $k=$ number of studies 
Table 3. Characteristics of Disasters and Disaster Experiences in Empirical Studies Examining Posttraumatic Stress

in Youth Following a Disaster $(k=96$; Total $N=74,154)$

\begin{tabular}{|c|c|c|}
\hline Variable & $\boldsymbol{k}$ & $\%$ of studies \\
\hline \multicolumn{3}{|l|}{ Publication Year } \\
\hline Prior to 1990 & 3 & 3.1 \\
\hline 1990-1999 & 24 & 25.0 \\
\hline $2000-2008$ & 69 & 71.9 \\
\hline \multicolumn{3}{|l|}{ Country of study } \\
\hline United States & 50 & 52.1 \\
\hline Turkey & 8 & 8.3 \\
\hline Armenia & 5 & 5.2 \\
\hline India & 5 & 5.2 \\
\hline Greece & 4 & 4.2 \\
\hline Sri Lanka & 3 & 3.1 \\
\hline Australia & 3 & 3.1 \\
\hline United Kingdom & 3 & 3.1 \\
\hline France & 2 & 2.1 \\
\hline
\end{tabular}


Table 3 cont.

Kenya

Poland

Canada

China

Iran

Japan

Nicaragua

Russia

Taiwan

Thailand

Ukraine

Disaster type

Natural

Man-made

Disaster category

Earthquake

Hurricane

2

2

1

1

1

1

1

1

1

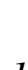

1

1

62

34

23

21
64.6

35.4

23.96

2.1

2.1

1.0

1.0

1.0

1.0

1.0

1.0

1.0

1.0

1.0

21.88 
Table 3 cont.

Terrorism

20.83

Tsunami

20

7.29

Flood

7

5.21

Tornado

5

4.17

Fire/wildfire

4

4.17

Boat disaster

4

4.17

Nuclear waste disaster

4

3.13

Sniper attack/shooting

3

3

3.13

Other explosion

2

2.08

Most studied specific disasters

9/11 attacks

12

12.5

2004 Indian Ocean Tsunamis

7

7.3

Hurricane Andrew

7

7.3

Hurricane Katrina

6

6.3

1999 Turkey Earthquake

6

6.3

Death Toll

$$
<25
$$


Table 3 cont.

17.8

$101-1000$

16

13.3

$1001+$

12

Loss of family member

41

45.6

Loss of friend

38

39.6

Peritraumatic threat to self

29

30.2

General/unspecified peritraumatic distress

16

16.7

Note: $k=$ number of studies 
Table 4. Stem-and-Leaf Plot of All Effect Sizes ( $r \mathrm{~s})$

\begin{tabular}{cl}
\hline Stem & \multicolumn{1}{c}{ Leaf } \\
\hline .7 & $13,30,36$ \\
.6 & $08,18,22,42$ \\
.5 & 11,82 \\
.4 & $10,57,99$ \\
.3 & $05,06,09,10,30,50,50,54,96$ \\
.2 & $43,69,87$ \\
.1 & $00,00,40,55,56,80,85,92,95,97$ \\
.0 & 03,30 \\
-.0 & 10,79 \\
-.1 & 12 \\
-.2 & \\
-.3 & 00 \\
-.4 & \\
-.5 & 35 \\
-.6 & \\
-.7 & \\
-.8 &
\end{tabular}

Note: Values in left column represent the first digit of the effect size, the correlation coefficient $(r)$, and the values in the right column represent the second and third digits of the effect size. 
Table 5. Stem-and-Leaf Plot of Gender Effect Sizes ( $r \mathrm{~s})$

\begin{tabular}{cl}
\hline Stem & \multicolumn{1}{c}{ Leaf } \\
\hline .5 & \\
.4 & 00,00 \\
.3 & $50,50,90,90$ \\
.2 & $10,11,20,30,80$ \\
.1 & $00,00,10,13,20,20,30,30,37,40,40,50,60,70,70,70,80,80$ \\
.0 & $10,10,29,39,50,50,50,55,59,70,80$ \\
-.0 & 20,38 \\
-.1 & $40,49,60$ \\
-.2 & \\
-.3 & \\
-.4 & 28,52 \\
-.5 & \\
\hline
\end{tabular}

Note: Values in left column represent the first digit of the effect size, the correlation coefficient $(r)$, and the values in the right column represent the second and third digits of the effect size. 
Table 6. Effects of Proximity, Peritraumatic Distress, and Disaster-related Loss on Youth Post-disaster PTS:

Results of Random-Effects Meta-analyses

\begin{tabular}{lcccccccc}
\hline Analysis & K & Total N & Pooled r & SD $_{\mathbf{r}}$ & SE $_{\mathbf{r}}$ & Z & FSN & $\chi^{2}$ \\
\hline Proximity to Disaster & 14 & 14,834 & .33 & .198 & .05 & 6.24 & 2,810 & 1315.11 \\
$\begin{array}{l}\text { Peritraumatic Distress } \\
\quad\end{array}$ & & & & & & & & \\
$\quad$ Threat to Self & 13 & 11,593 & .34 & .110 & .03 & 11.32 & 80 & 322.97 \\
$\quad \begin{array}{l}\text { General / Unspecified } \\
\text { Loss of loved one or friend }\end{array}$ & 14 & 12,347 & .38 & .150 & .04 & 9.50 & 6,523 & 358.3 \\
\end{tabular}

Note: $\mathrm{K}=$ number of studies included in analysis; Total $\mathrm{N}=$ number of children included in analysis; Pooled $\mathrm{r}=$ pooled correlation effect size; $\mathrm{SD}_{\mathrm{r}}=$ standard deviation of pooled $\mathrm{r} ; \mathrm{SE}_{\mathrm{r}}=$ standard error of pooled $\mathrm{r} ; \mathrm{Z}=\mathrm{z}$-score of pooled $\mathrm{r}$; FSN $=$ fail-safe number of studies needed to overturn the significant findings; $\chi^{2}=$ chi-square random effects model variability of pooled r. 
Table 7. Effects of Disasters on Youth PTS by Measurement Psychometric Quality, Informant, Study Period, and Measurement Mode: Results of Random-Effects Meta-analyses

\begin{tabular}{|c|c|c|c|c|c|c|c|c|}
\hline Analysis & $\mathbf{K}$ & Total N & Pooled r & SDr & SEr & $\mathbf{Z}$ & FSN & $\chi^{2}$ \\
\hline \multicolumn{9}{|l|}{ Measurement quality } \\
\hline Sound & 37 & 30,689 & .20 & .161 & .026 & 7.48 & 28,239 & 1238.59 \\
\hline Methodological quality unknown & 5 & 2,208 & .11 & .329 & .147 & .76 & - & 297.41 \\
\hline \multicolumn{9}{|l|}{ Informant } \\
\hline Child & 39 & 31,189 & .20 & .168 & .027 & 7.43 & 31,016 & 1369.51 \\
\hline Parent & 10 & 3,192 & .12 & .256 & .081 & 1.49 & - & 268.5 \\
\hline \multicolumn{9}{|l|}{ Post-disaster Period } \\
\hline$<1$ year & 28 & 30,234 & .20 & .15 & .028 & 7.08 & 14,495 & 1071.76 \\
\hline$>1$ year & 14 & 2,663 & .09 & .354 & .095 & .933 & - & 400.54 \\
\hline \multicolumn{9}{|l|}{ Measurement Mode } \\
\hline Multi-method & 9 & 3,358 & .20 & .155 & .052 & 3.86 & 438 & 123.77 \\
\hline Mono-method & 33 & 29,539 & .19 & .181 & .032 & 6.07 & 14,770 & 1478.16 \\
\hline \multicolumn{9}{|l|}{ PTS Definition } \\
\hline Continuous & 25 & 11,735 & .21 & .13 & .03 & 7.10 & 11,618 & 228.81 \\
\hline
\end{tabular}


Table 7 cont.

$\begin{array}{lllllllll}\text { Categorical } & 32 & 26,413 & .19 & .20 & .04 & 5.29 & 10,558 & 1655.31\end{array}$

Note: $\mathrm{K}$ = number of studies included in analysis; Total $\mathrm{N}=$ number of children included in analysis; Pooled $\mathrm{r}=$ pooled correlation effect size; $\mathrm{SD}_{\mathrm{r}}=$ standard deviation of pooled $\mathrm{r} ; \mathrm{SE}_{\mathrm{r}}=$ standard error of pooled $\mathrm{r} ; \mathrm{Z}=\mathrm{z}$-score of pooled $\mathrm{r}$; FSN $=$ fail-safe number of studies needed to overturn the significant findings; $\chi^{2}=$ chi-square random effects model variability of pooled r. 


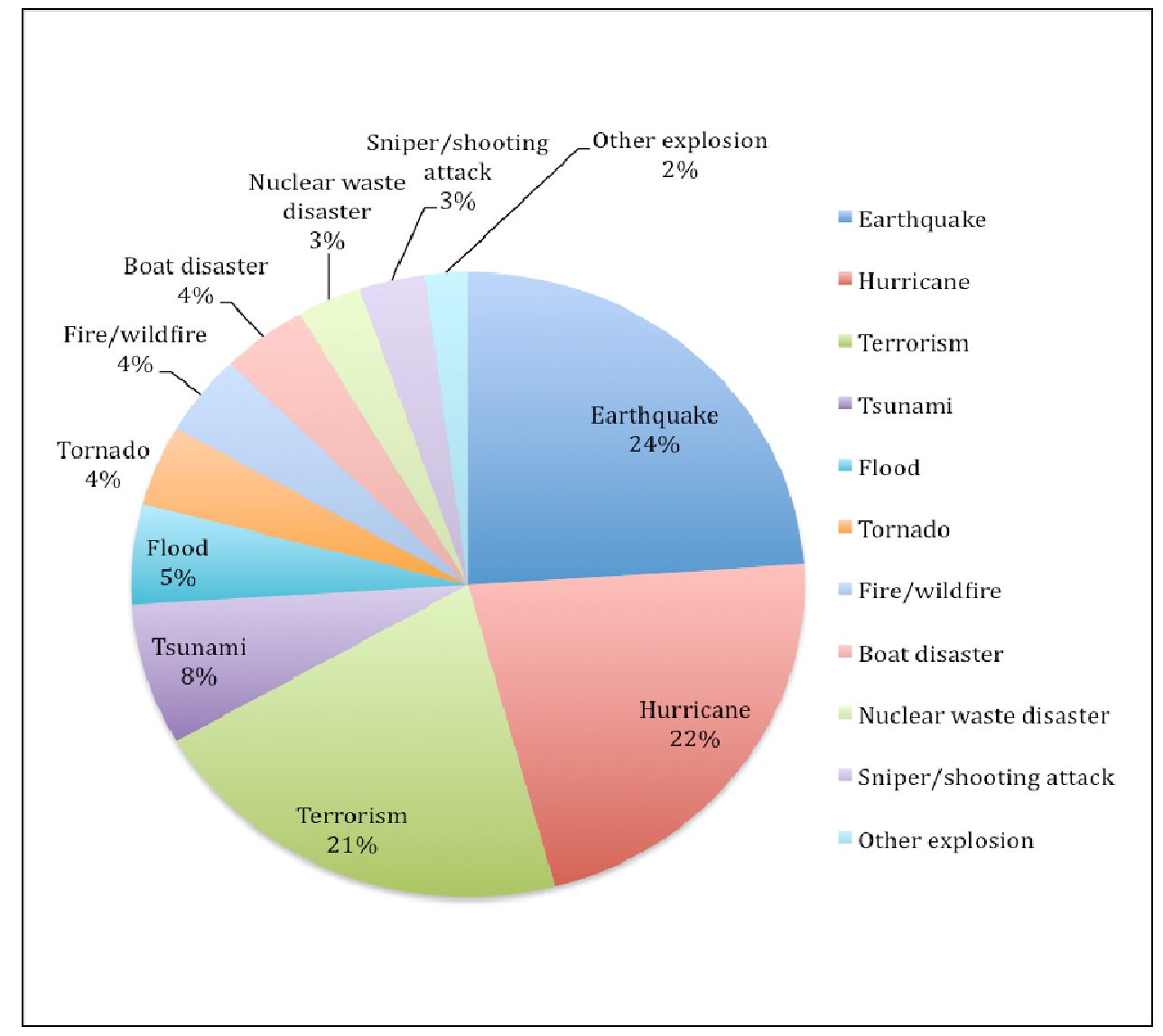

Figure 1. Percentage of Type of Disaster 


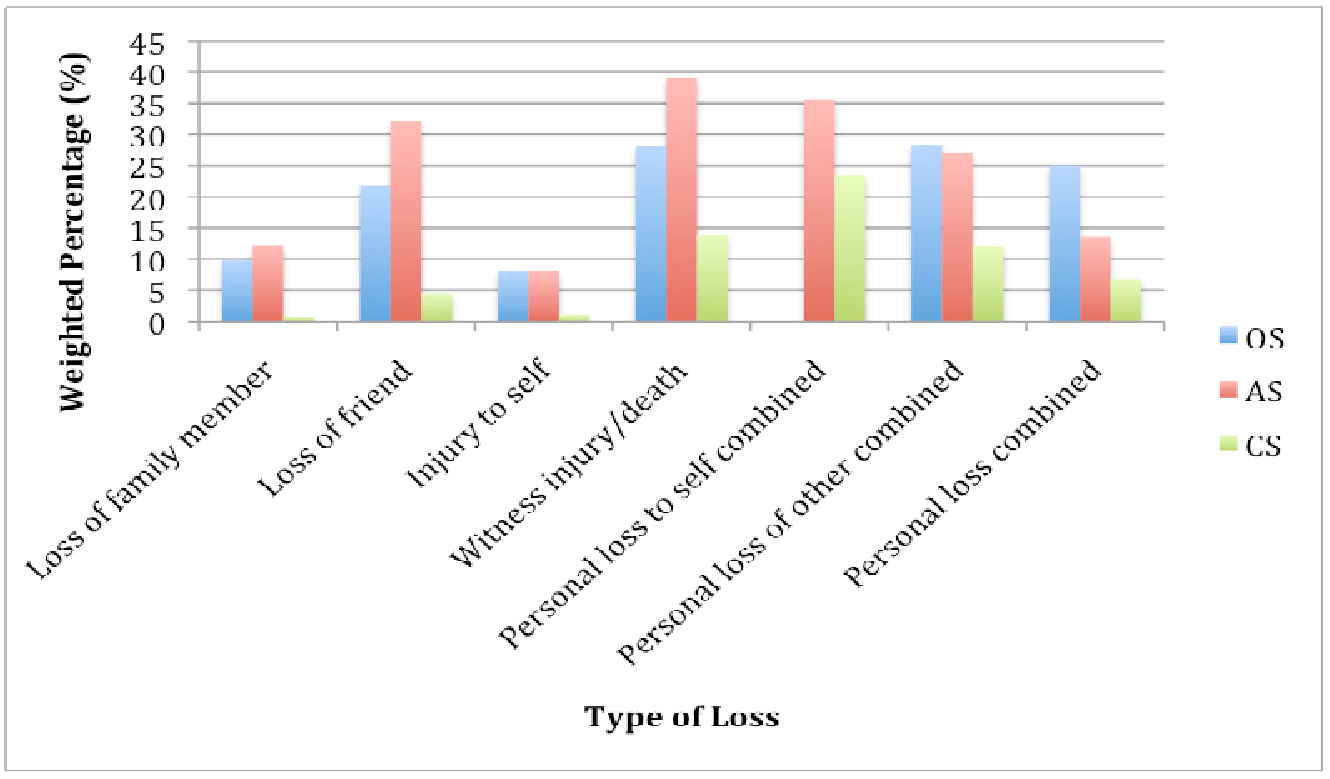

Figure 2. Weighted Prevalence of Post-disaster Loss and Injury 


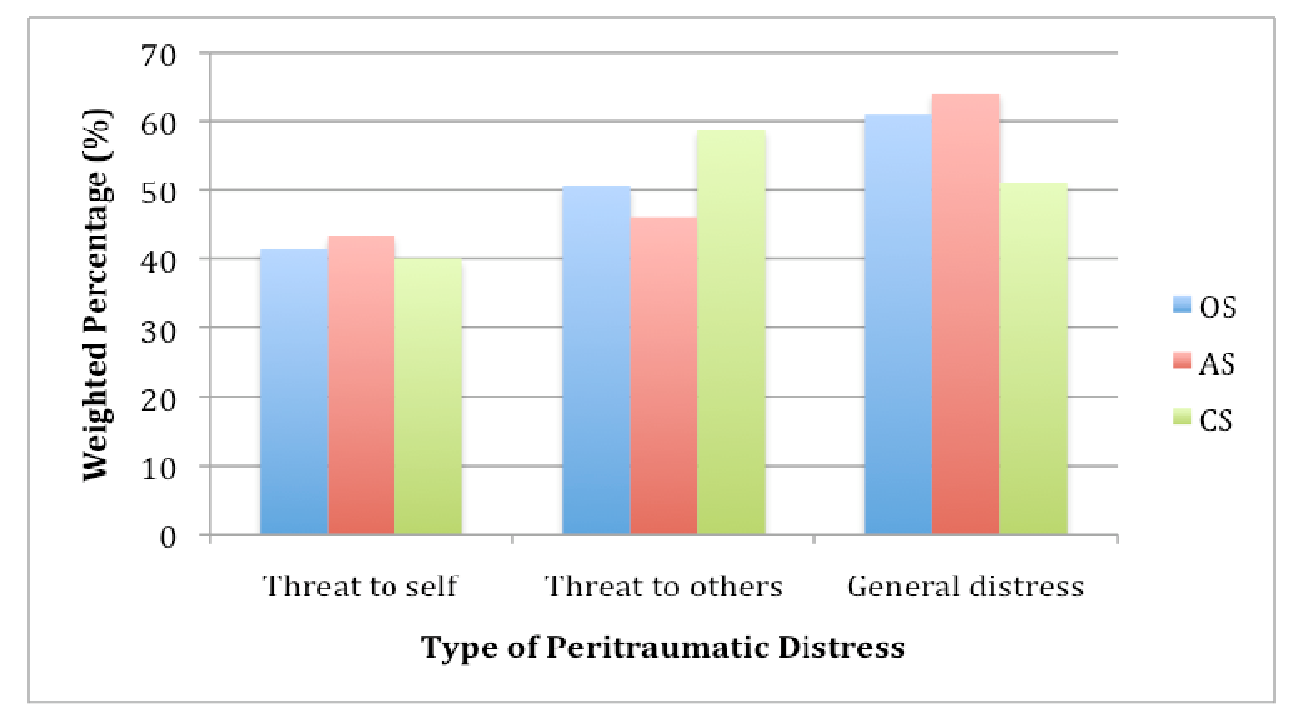

Figure 3. Weighted Prevalence of Peritraumatic Distress in the Overall, Affected, and Combined Samples 


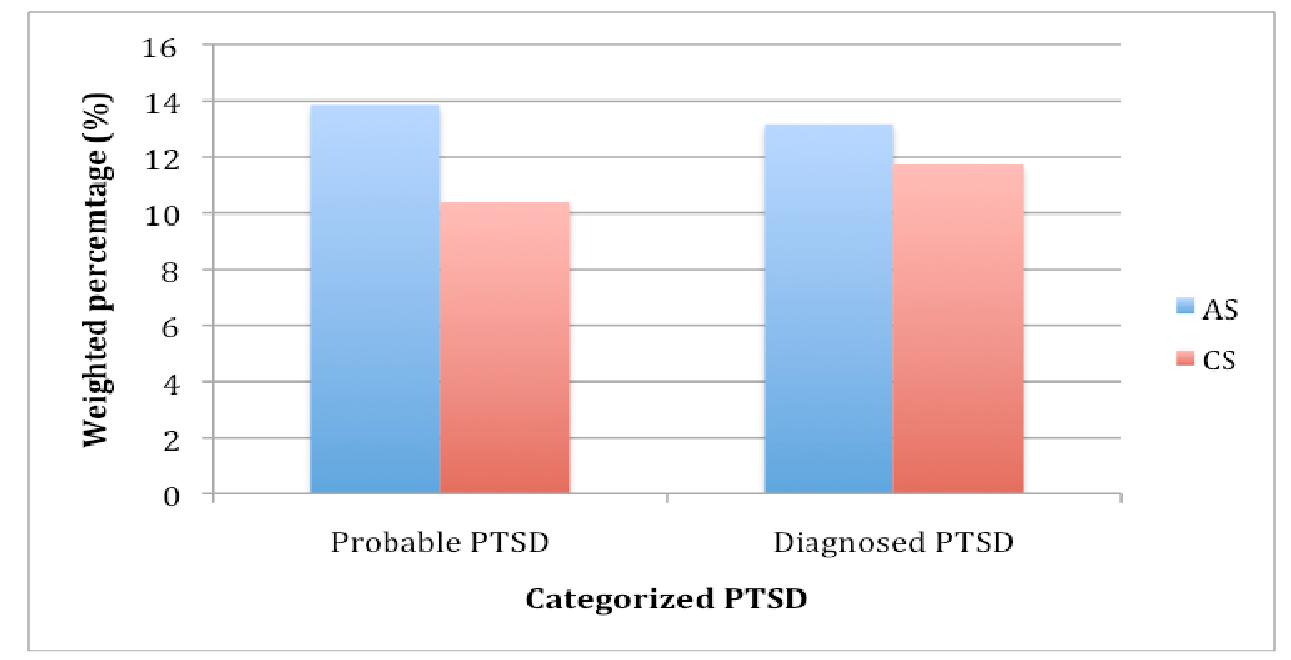

Figure 4. Weighted Prevalence of Probable and Diagnosed PTSD in the Affected and Comparison Samples 


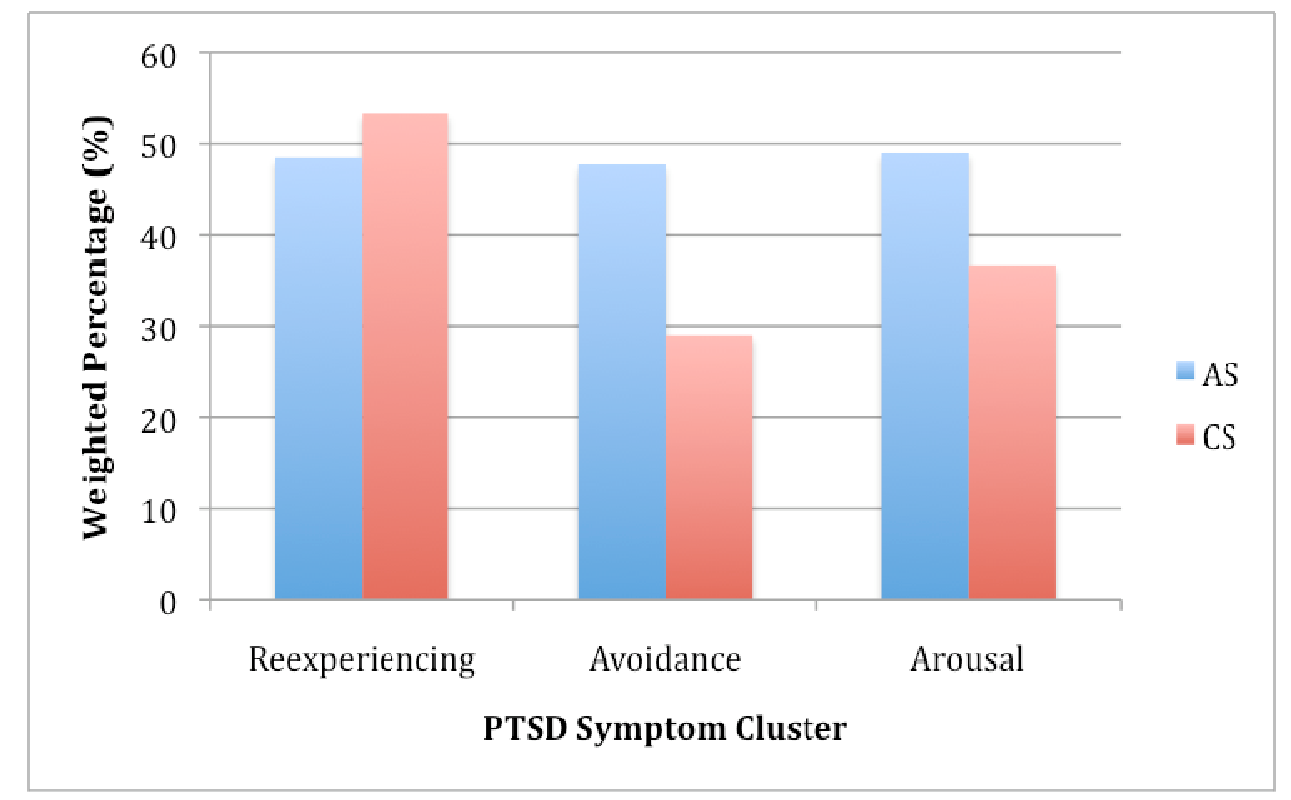

Figure 5. Weighted Prevalence of Reexperiencing, Avoidance, and Arousal Symptoms in the Affected and Comparison Samples 


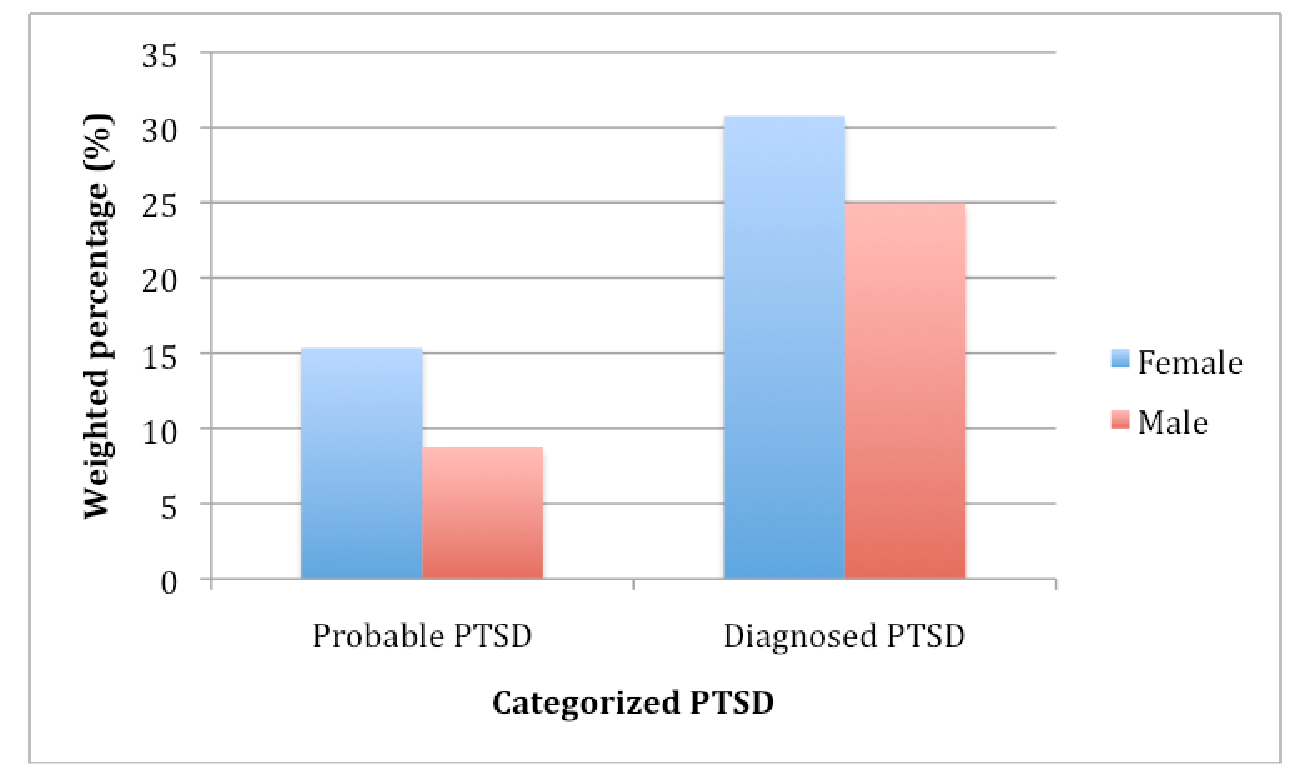

Figure 6. Weighted Prevalence of Probable and Diagnosed PTSD by Gender 


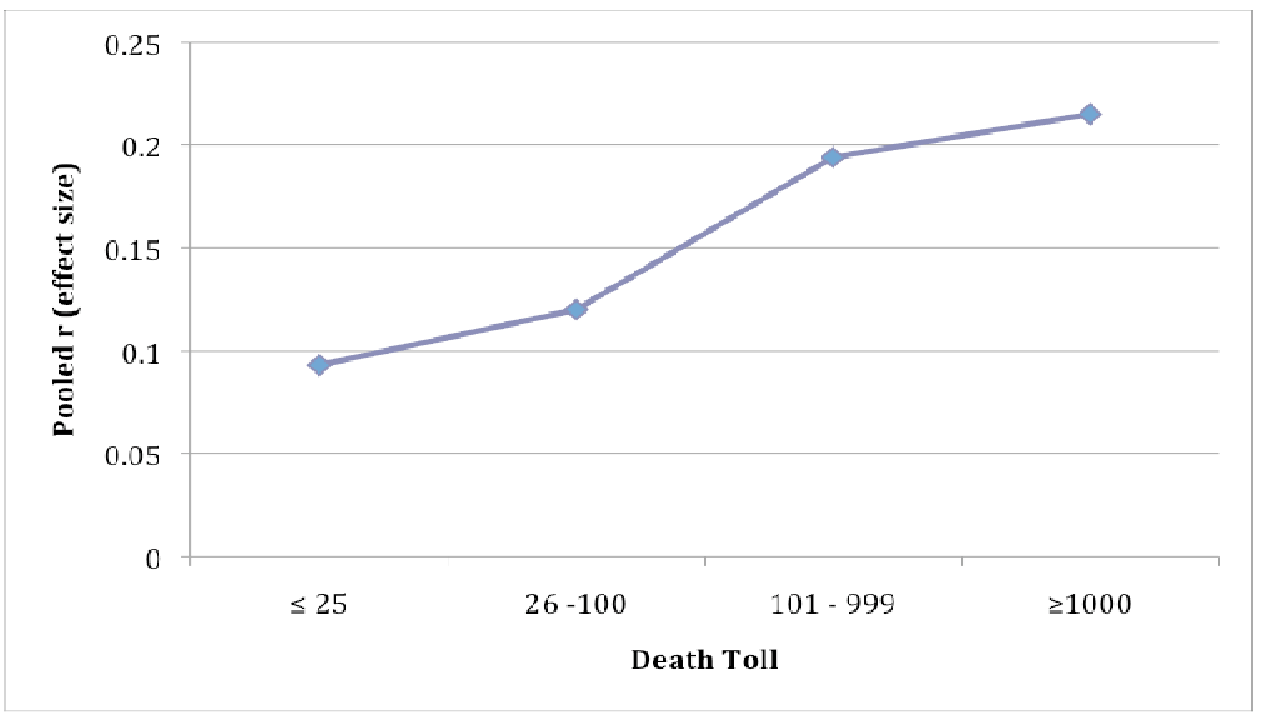

Figure 7. Linear Trend in Pooled $r$ Effect Size of PTS Symptoms in Relation to Death Toll 